University of Rhode Island

DigitalCommons@URI

Open Access Master's Theses

2017

\title{
Social Outcomes of Coastal Ecosystem Management: The Role of Stakeholder Values and Norms
}

Lauren I. Josephs

University of Rhode Island, lauren_josephs2@uri.edu

Follow this and additional works at: https://digitalcommons.uri.edu/theses

\section{Recommended Citation}

Josephs, Lauren I., "Social Outcomes of Coastal Ecosystem Management: The Role of Stakeholder Values and Norms" (2017). Open Access Master's Theses. Paper 1069.

https://digitalcommons.uri.edu/theses/1069

This Thesis is brought to you for free and open access by DigitalCommons@URI. It has been accepted for inclusion in Open Access Master's Theses by an authorized administrator of DigitalCommons@URI. For more information, please contact digitalcommons-group@uri.edu. 
SOCIAL OUTCOMES OF COASTAL ECOSYSTEM

MANAGEMENT: THE ROLE OF STAKEHOLDER

VALUES AND NORMS

BY

LAUREN I. JOSEPHS

A THESIS SUBMITTED IN PARTIAL FULFILLMENT OF THE

REQUIREMENTS FOR THE DEGREE OF

MASTER OF SCIENCE

IN

BIOLOGICAL AND ENVIRONMENTAL SCIENCES

UNIVERSITY OF RHODE ISLAND

2017 


\section{MASTER OF SCIENCE THESIS}

OF

\section{LAUREN I. JOSEPHS}

\section{APPROVED:}

Thesis Committee:

Major Professor $\quad$ Austin T. Humphries
David Bidwell
Tracey M. Dalton
Nasser H. Zawia
DEAN OF THE GRADUATE SCHOOL

UNIVERSITY OF RHODE ISLAND

2017 


\begin{abstract}
With human use of coastal ecosystems at an all-time high, a current challenge for conservation is to integrate social factors into management. Studies with this aim have focused primarily on monetary valuations of ecosystem functions, overlooking the psycho-social motivations underlying conservation and management. Our study leverages a values-beliefs-norms framework of environmental attitudes in interviews with residents and tourists of Martha's Vineyard (MA). Specifically, we assess the role of human values, perceptions, and preferences in evaluating what constitutes social viability in coastal ecosystem management. Our results show that situational constraints to public understanding of conservation initiatives can undermine support even among individuals with strong pro-environmental attitudes. Furthermore, our findings suggest that public support for individual conservation initiatives can misconstrue differences and trade-offs that arise between stakeholder groups when considering overall management priority. Future research should address whether ecological success of conservation efforts acts as an additional context-dependency of social viability.
\end{abstract}




\section{ACKNOWLEDGMENTS}

First and foremost, I would like to express my gratitude to my major professor, Dr. Austin Humphries, for his dedication in his role as my mentor, and for the sincere honor and pleasure of being his first graduate student at the University of Rhode Island. I also extend great thanks to my committee members David Bidwell and Tracey Dalton, and former committee member Caroline Gottschalk-Druschke, for their continued guidance in the development of both my research project and this manuscript. A special acknowledgement is given to David Bidwell for his constant willingness to sit with me and tackle ever-evolving questions on statistics. I would like to thank my collaborators Marty Chintala, Suzy Avayzian, Mary Schoell, and Anna Gerber Williams at the U.S. Environmental Protection Agency Atlantic Ecology Division; Suzan Bellincampi, Josey Kirkland, and Savannah Lawson at the Mass Audubon Felix Neck Wildlife Sanctuary; and David Grunden at the Martha's Vineyard Shellfish Group. A special thanks is extended to Marion Hammond for her warm presence in an even warmer office over long field-season days at the wildlife sanctuary. Furthermore, I would like to thank Evans Arizi, Maximilian Benedikt Bucher, Paul Carvalho, John Jack Girard, Diky Suganda, Katie Viducic, and Elle Wibisono; the O.G. Humphries Team, for being my academic 'Ohana. Lastly, the deepest thanks go to my mom, my dad, and my brother Eric for always standing firmly beside me as I reach for the next big thing. 


\section{PREFACE}

The following thesis has been submitted in manuscript format following the formatting guidelines of the journal Conservation Letters. 


\section{TABLE OF CONTENTS}

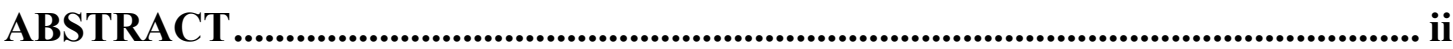

ACKNOWLEDGMENTS .............................................................................................. iii

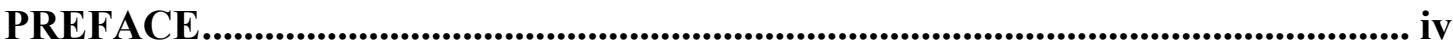

TABLE OF CONTENTS ...............................................................................................v

LIST OF TABLES ............................................................................................................ vii

LIST OF FIGURES ................................................................................................. viii

CHAPTER 1 .........................................................................................................................

ABSTRACT

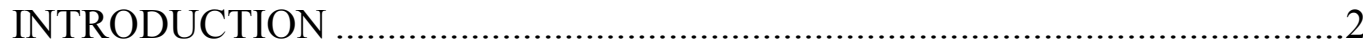

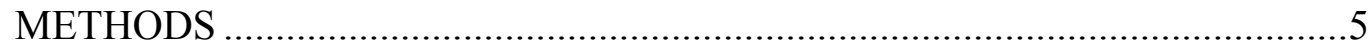

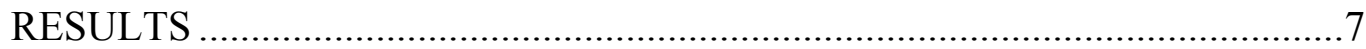

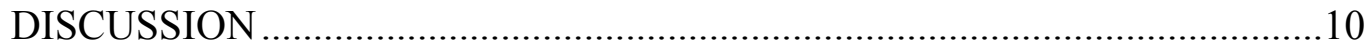

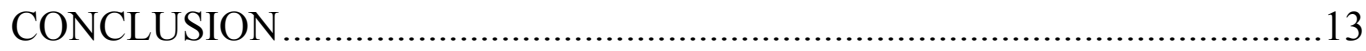

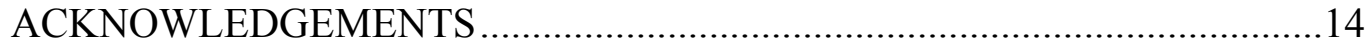

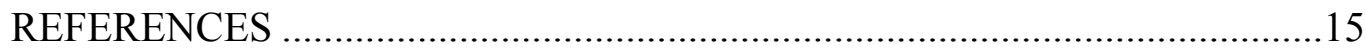

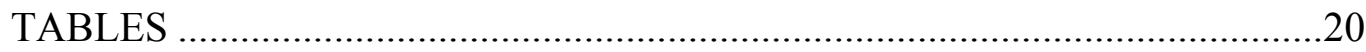

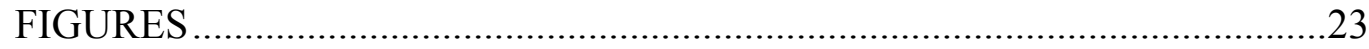

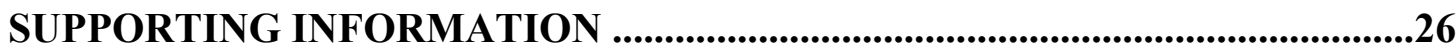

APPENDIX S1 (VALUES-BELIEFS-NORMS THEORY) .................................26

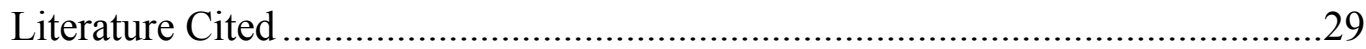

APPENDIX S2 (STRUCTURAL EQUATION MODELING).............................32

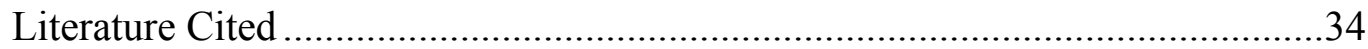


Tables

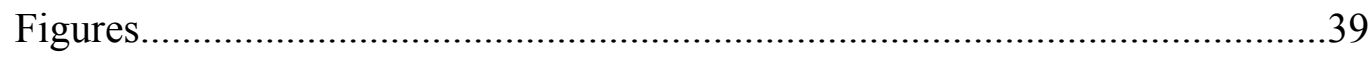

APPENDIX S3 (DEFINITIONS OF RESTORATION SUCCESS).................41

APPENDIX S4 (SUPPLEMENTARY TABLES) .........................................43

APPENDIX S5 (SUPPLEMENTARY FIGURES) .......................................44

APPENDIX S6 (SURVEY INSTRUMENT) ............................................46 


\section{LIST OF TABLES}

TABLE

PAGE

Table 1. List of variables including factors, reliability of latent factors using Cronbach's alpha (Sim \& Wright 2005), descriptions, and data type........................................20

Table 2. Value-Belief-Norm (VBN) variable mean scores and measures of dispersion.

Table 3. Results from independent-samples t-tests of coastal management preferences by Martha's Vineyard residents (R) and tourists (T), and shellfishers (S) and non-shellfishers (NS) 


\section{LIST OF FIGURES}

FIGURE

PAGE

Figure 1. Study site including a.) locations of interview recruitment sites relative to the living shoreline restoration project site, b.) living shoreline restoration project, and c.) detail of living shoreline design using coconut fiber logs and bags of oyster shell as a biodegradable shoreline stabilization and salt marsh habitat facilitation structure. ....23

Figure 2. Structural equation model (SEM) of restoration project support predicted by values-beliefs-norms (VBN) attitudinal variables and an individual's level of understanding of the project. Variables represented by squares are state variables and those in circles are latent variables. Demographic variables are visually represented as a single state variable to simplify the figure, but predictive pathways from all five variables were tested. Values on pathways are regression coefficients, and '*' indicates significance at the $\mathrm{p}<0.05$ level.

Figure 3. Study participants' prioritization of strategies for the conservation and management of coastal salt ponds on Martha's Vineyard. .25 


\section{CHAPTER 1}

Social outcomes of coastal ecosystem management: the role of stakeholder values and norms

\section{Authors}

Lauren I. Josephs ${ }^{1}$; Austin T. Humphries ${ }^{2}$

Manuscript in preparation for Conservation Letters

${ }^{1}$ University of Rhode Island, Kingston, RI; lauren_josephs2@uri.edu

${ }^{2}$ University of Rhode Island, Kingston, RI, humphries@uri.edu 


\begin{abstract}
With human use of coastal ecosystems at an all-time high, a current challenge for conservation is to integrate social factors into management. Studies with this aim have focused primarily on monetary valuations of ecosystem functions, overlooking the psycho-social motivations underlying conservation and management. Our study leverages a values-beliefs-norms framework of environmental attitudes in interviews with residents and tourists of Martha's Vineyard (MA). Specifically, we assess the role of human values, perceptions, and preferences in evaluating what constitutes social viability in coastal ecosystem management. Our results show that situational constraints to public understanding of conservation initiatives can undermine support even among individuals with strong pro-environmental attitudes. Furthermore, our findings suggest that public support for individual conservation initiatives can misconstrue differences and trade-offs that arise between stakeholder groups when considering overall management priority. Future research should address whether ecological success of conservation efforts acts as an additional context-dependency of social viability.
\end{abstract}

\title{
INTRODUCTION
}

The conservation of diminished coastal and marine resources has emerged as one of the greatest challenges within a rapidly changing global environment (Vitousek et al. 1997; Spalding et al. 2014). A shifting climate, globalization, and increased anthropogenic impacts in coastal zones have introduced new ecological and social complexity (Liu et al. 2007). For example, part of the difficulty of managing coastal and marine habitats lies in the accommodation of multiple user-groups (Agardy 1993). This can mean balancing a tourism-based economy with the needs of other stakeholders such 
as residents and resource-dependent communities. Thus, conservation and management solutions must incorporate preferences and trade-offs in multiple ecosystem components that span social and ecological dimensions (Berkes et al. 2000).

Coastal habitats provide a wide variety of ecosystem services and support diverse ecological communities, but have been severely degraded over the last three decades (MEA 2005). Salt marshes are one of the most impacted of all coastal habitats due in large part to development practices (Lotze et al. 2006). As a result, coastal salt marshes have become the focus of many conservation and restoration efforts. To be successful, nature-based strategies are needed that support ecologically and socially desirable systems, and not shoreline armoring that drives further habitat loss and disrupts landwater exchange (Bozek and Burdick 2005). However, the development of nature-based coastal protection interventions are still in their infancy, particularly in high-energy salt marshes (Gittman et al. 2016). The conservation value of these approaches will depend on both ecological and social responses to their implementation.

To utilize a coupled social-ecological systems framework in conservation management, it is necessary to understand how variables from both systems interact and contribute to success. Currently, empirical understanding of relevant ecological factors far exceeds that for social factors (de Juan et al. 2017). Furthermore, the framework for understanding what it means for management to be socially viable is not well established, and rarely operationalized (but see Klain \& Chan 2012; Arkema et al. 2015). While socioeconomic assessments of coastal management efforts are becoming more common, monetary valuations dominate (Le Gentil \& Mongruel 2015). Social-psychological research on environmental attitudes and behavior, however, has demonstrated that people 
are motivated by far more than economic considerations (Stern 2000). In fact, many have argued that conservation and management conflicts are often a struggle of social values rather than technical expertise or ecological processes (e.g., Mascia et al. 2003; Gelcich et al. 2005). Yet, few studies have explicitly examined how social variables are related to conservation and management success or viability.

Human values are described as preferences for certain modes of conduct (means), or outcomes (ends), that act as a motivational framework to guide behavior (Schwartz 1994). This framework has been adapted to explain the role of personal values in motivating environmentally significant behavior for conservation (Stern et al. 1993). This adaptation suggests that concern for environmental issues is based on matters of altruism (a social-altruistic values orientation), self-interest (egoistic orientation), or in the interest of 'all living things' (biospheric orientation). In natural resources conservation and management, the extent of concern acts as the precursor to attitudes that shape policy or project support (Appendix S1). Therefore, an understanding of human values associated with conservation support and viability can help managers anticipate behavior (e.g., compliance) or identify potential conservation alternatives.

This study aims to inform our understanding of effective social-ecological management by using human values, perceptions, and preferences in assessing what facilitates social viability in coastal conservation management. To operationalize this, we conducted semi-structured interviews with individuals representing multiple stakeholder groups in coastal communities across Martha's Vineyard (MA). Here, a nature-based salt marsh stabilization project was created with a 'living shoreline' design that uses biodegradable materials. The novelty of this technique coupled with the high visibility 
associated with the project provides a social landscape well suited for exploring human responses and preferences. Specifically, we sought to determine how social variables influenced project support and mediated choices for potential alternative management strategies.

\section{METHODS}

\section{Study Setting}

This study focuses on a community dealing with poor water quality and coastal erosion in Martha's Vineyard. As part of a response to these issues, a restoration effort was undertaken along an eroded salt marsh in Summer 2016. The restoration project involved installation of coconut fiber logs (16" diameter x 12' length) and bags filled with oyster shells (12" width x 24" length) in Sengekontacket Pond (Figure 1). This 'living shoreline' design was implemented with the goal of reducing erosion and improving water quality through recruitment of salt marsh vegetation.

\section{Survey Design and Data Collection}

Our 27-question survey instrument was created with multidisciplinary input from social scientists, ecologists, and managers and it included two parts with both quantitative and qualitative measures. First, we collected information using semi-structured, one-onone interviews on an individual's relationship to Sengekontacket Pond, and the modes

and frequencies with which they used it. Second, we allowed participants to self-report basic socioeconomic information, behavioral norms related to environmental issues, beliefs about the state of the environment, underlying personal values, their level of confidence in their understanding of the goals and design of the living shoreline restoration project, their support for the restoration project, and preferences for pond 
restoration management scenarios. An individual's understanding of the restoration project is described as 'confidence' because participants were not required to prove that they understood the project's goals and design. Environmental beliefs were gauged using the New Ecological Paradigm (NEP) (Dunlap \& Van Liere 1978) scale and underlying personal values were measured using Schwartz's value items organized into environmentally-relevant value orientations (Stern et al. 1993).

The coastal salt ponds on Martha's Vineyard, including Sengekontacket Pond where the living shoreline project is located, experience heavy use by both the residents living on the island, as well as the tourists who vacation there during the summer months (June - September). In particular, Sengekontacket Pond sees a wide range of recreational use along its shoreline which includes private residences, conservation land, and public beach. In an effort to capture this complexity for data collection, we targeted individuals that fell within a 'community of interest' who either, (a) visited a public beach along the pond's eastern side (Joseph Sylvia State Beach), (b) visited a nature reserve along the western side (The Mass Audubon Felix Neck Wildlife Sanctuary), (c) lived or vacationed in a development along the southwestern side (Ocean Heights), or (d) held an active recreational shellfishing permit for the pond (Figure 1). In-person interviews were performed during peak tourist season in Summer 2016 and interviews not done in person were with shellfish permit-holders, which were conducted over the phone because of scheduling difficulty. The only difference between interviews conducted in person ( $\mathrm{n}=$ $103)$ and those conducted over the phone $(n=7)$ were the self-report measures; phone recruits completed these through Qualtrics online survey software.

\section{Analyses}


We used structural equation modeling (SEM) to investigate the links between social variables and project support within the dataset. SEM is an extension of multiple regression analysis that is able to test relationships between observed and latent variables. In SEM, predictive pathways between variables are established a priori and measures of model fit and explained variance indicate how well this hypothesized structure fits with a given data set. In this study, we designed SEM structure in accordance with the relationships outlined by Values-Beliefs-Norms (VBN) theory (Stern et al. 1999). Given that the majority of latent variables stem from scales rigorously tested in previous literature, we used simple tests of reliability (Cronbach's alpha; Gliem \& Gliem 2003) to check their validity (Table 1). We used partial-least-squares (PLS) regression as the method of estimation in our SEM due to a relatively small sample size compared with model complexity (Appendix S2). Individual relationships between variables of interest were investigated further with one-way ANOVAs and pairwise comparisons using t-tests. We also tested for differences across stakeholder groups in the priorities assigned to coastal management alternatives using t-test pairwise comparisons.

\section{RESULTS}

\section{Sample Description}

A total of 110 individual interviews were conducted between June and September 2016. Out of the these interviews, 89 progressed far enough to be included in final data analyses. Sample sizes of individual analyses, however, vary due to the rights of study participants to refuse questions. Overall, participants skewed older, were almost evenly split by gender, and trended towards higher affluence with high levels of education and annual household income compared to national trends (US Department of Commerce 
2015). Forty-five percent of interviewees represented Martha's Vineyard residents and the other 55\% were tourists (Table S3b).

\section{Environmental Attitudes}

Overall, interview participants held strong pro-environmental attitudes (Table 2). Personal values oriented towards altruism, traditionalism and biospherism were scored similarly on average, with biospherism being highest overall. Personal values oriented towards egoism were scored lowest overall. The average NEP score among participants was 27.92 , indicating a strong belief that ecosystems are currently threatened by human societies. On average, individuals were more concerned about environmental threats to plants, animals, and the local community than about environmental threats to themselves and their families.

\section{Project Support}

Overall, results indicated the 'living shoreline' approach was a socially viable option among this community of interest. Less than $12 \%$ of study participants expressed an attitude of neutrality or opposition towards the restoration effort in Sengekontacket Pond. Results from the SEM indicated relationships between social variables that are consistent with VBN theory (Stern et al. 1999) (Figure 2). An individual's concern for the health of the world's ecosystems (reflected in NEP score) was positively related to their awareness of the consequences of degraded ecosystems $(\beta=0.43, \mathrm{p}<0.05)$, and this awareness was positively related to the strength of environmentally-relevant personal norms (e.g. staying informed on environmental issues) $(\beta=0.39, \mathrm{p}<0.05)$. However, the VBN causal chain did not significantly explain the variance seen in restoration project support. Instead, multi-model analysis showed a significant predictive pathway between an individual's 
stated project understanding and restoration project support. Additionally, a simple pathway from exogenous demographic variables through stated project understanding explained twice as much of the variance in project support than the entire VBN pathway. According to the model, increases in stated project understanding significantly predicted increases in project support $(\beta=0.29, \mathrm{p}<0.05)$, while increases in the strength of personal environmental norms did not $((\beta=0.07, \mathrm{p}=0.598)$. This finding is reinforced by patterns among individuals who expressed higher (moderate or strong) and lower support (neutrality or opposition) towards the project. Individuals in these categories showed no significant difference in NEP scores $\left(\mathrm{F}\right.$-value $=3.25_{82,1}, \mathrm{p}=0.263$, but individuals expressing lower support reported lower confidence in project understanding $\left(\mathrm{F}\right.$-value $\left.=0.13_{84,1}, \mathrm{p}<0.05\right)($ Table S3c $)$

\section{Alternative Management Strategies}

Despite strong support for the living shoreline project, a majority of stakeholders did not see habitat restoration approaches as the primary solution for Sengekontacket Pond's degraded ecosystem (Figure 3). Over 50\% of study participants chose a coastal management strategy other than habitat restoration when asked to indicate which should be the priority for future initiatives. In particular, restrictions on new development in coastal watersheds and new regulations on septic and sewer systems were cited as important alternatives. This broader consideration of coastal management approaches also introduced differences between stakeholder groups (Table 3). On average, tourists assigned higher priority to habitat restoration $\left(\mathrm{F}\right.$-value $\left.=0.77_{81,1}, \mathrm{p}<0.05\right)$, and residents assigned higher priority to dredging and breaching coastal ponds (F-value $=37.66_{81,1}, \mathrm{p}<$ 0.05). Recreational shellfishers felt that habitat restoration was of lower priority (F-value 
$\left.=0.35_{81,1}, \mathrm{p}<0.05\right)$ and updates to septic and sewer systems were of higher priority (Fvalue $=2.93_{81,1}, \mathrm{p}<0.05$ ) compared to individuals who did not regularly shellfish (Figure $\mathrm{S} 4 \mathrm{c})$.

\section{DISCUSSION}

Our results suggest that an individual's confidence in understanding conservation management initiatives can mediate support more strongly than general environmental attitudes. Here, low levels of project support were not explained by weak environmental concern, but instead by a stated weak understanding of project design and objectives. Despite strong overall support for the living shoreline restoration strategy, a diversity of perspectives arose when considering priorities for future coastal conservation and management initiatives. More than half of those interviewed felt that habitat restoration was not of highest priority, and this demonstrated mismatches in the preferences of different resource-user groups.

\section{Importance of Situational Factors}

As situational constraints to environmentally-significant behaviors increase, human values and beliefs lose explanatory power (Steg \& Vlek 2009). Syntheses of environmental behavior theory assert that actions are a product of internal and situational factors; that the effects of pro-environmental intent on performed behavior function relative to context (Guagnano et al. 1995; Maio 2003). In this study, we see the influence of situational constraints in the relationship between an individual's stated understanding of the restoration effort and their willingness to voice support for it. Our sample demonstrated a near unanimous attitudinal predisposition to act environmentally, but a portion expressed little to no understanding of how the restoration project aims to 
contribute to the coastal habitat. We identify this stated weak understanding as a situational factor rather than an internal condition because our sample showed no relationship between education and stated project understanding.

In case studies of other environmentally relevant behaviors, such as curbside recycling (Guagnano et al. 1995) and use of public transport (Collins \& Chambers 2005), environmental concern is shown to be deficient in overcoming the barriers presented by a lack of access to the resources necessary to perform a certain behavior. Here, we suggest that the instances of weak public understanding seen to diminish project support in our study could have resulted from a lack of access to information on the living shoreline initiative. If this is true, the state of public support for this initiative may benefit from targeted stakeholder engagement activities.

\section{Engagement \& Public Understanding}

In practice, public engagement ranges from direct participation of the public in development of policies and initiatives, to a simple transfer of information from managers to stakeholders (Rowe \& Frewer 2005). The latter describes the engagement mechanism used in an 'information-deficit' approach to scientific communication, the efficacy of which is contested (Druschke \& McGreavy 2016). In the 'information-deficit' model, a one-way flow of information from 'expert' to 'audience' is seen as sufficient to equip the public to employ scientific knowledge in their own decision-making.

Our results suggest that public support for the living shoreline project, although robust, may have benefited from deeper public understanding of the particular conservation management strategy. It is tempting to characterize this finding as support for an information-deficit approach to public engagement, however, all individuals in our 
study were given basic information regarding the goals and design of the living shoreline project prior to interviews. Individuals varied in how confidently they felt they understood the conservation initiative, despite being provided this information and independent of education level. Considering this, it will be important for studies to investigate other potential factors contributing to an individual's perception of their own ability to access and employ scientific knowledge. This is an objective that points to the utility of 'contextual' approaches to scientific communication and public engagement, which emphasize the context-dependencies of the public's relationship to scientific information (Druschke \& McGreavy 2016).

Public engagement efforts that target the specific exigency of a group can function as a form of democracy that facilitates both representativeness and the delivery of pertinent information (Wilsdon \& Willis 2004). Many of the individuals we interviewed who reported a weak understanding of the living shoreline project were disaffected towards matters of coastal conservation and management more generally. In some cases, we were asking them to weigh-in on a local initiative that they were previously unaware of. Lack of trust resulting from poor communication can act as a roadblock to policy support even among individuals where pro-environmental values and beliefs are strong (e.g., Stern 2008). Future studies should examine the links between public perceptions and local conservation and management processes, and in particular be able to account for interactions between the two.

\section{Integrated Conservation and Management}

It is important to note that coastal conservation and management goals often require comprehensive measures that stretch beyond the scope of a single initiative like the one 
in our study. In scaling up our assessment of public preferences, we see a more nuanced response to the living shoreline project. Studies have demonstrated user-groups to prioritize ecosystem functions differently (see de Juan et al. 2017), potentially leading to differences in perceptions of appropriate conservation measures. Our study suggests that strong public support for a nature-based conservation strategy does not necessarily translate to the prioritization of similar initiatives. Instead, we show heterogeneity in public preference and the potential for divergence between user-groups. For example, dredging coastal ponds to maintain tidal flushing was cited as an important coastal management strategy by island residents, and was notably unpopular among tourists. Dredging projects are often controversial (see Cutroneo et al. 2014) and the local context that substantiates them may be unavailable to tourists, promoting controversy.

Differences in opinion were also seen within particular resource-user groups. For instance, perceptions of the importance of updating septic and sewer systems were significantly higher among residents who regularly shellfished in the region's coastal ponds compared to those that did not. Considering the problem of polluted waters as potentially more salient among those who harvest from them, this result may not be surprising. However, new septic and sewer regulations infer a cost to homeowners, highlighting a management trade-off between residents who rely on clean water for provisioning resources, and those looking to develop in coastal watersheds for personal use or to access a tourism economy.

\section{CONCLUSION}

The rate of change and complexity of coastal conservation implores that we identify, prioritize, and act quickly upon areas of agreement. This requires conservationists, 
managers, and stakeholder groups to work together in identifying areas of overlap and to address mismatches where they occur. Our results show that practitioners should consider situational constraints of stakeholder support beyond environmental ideologies as well as the trade-offs that exist between groups interacting in multiple-use coastal environments. These findings underscore the complexity of the human dimension in social-ecological coastal management and conservation. Careful consideration of social factors in the context of ecosystem functioning will equip coastal managers with the ability to determine locally viable policies and initiatives, thereby allowing for more appropriate allocation of limited resources. Future research should work to integrate public perceptions of management effectiveness, and to track these with ecological success in a coupled social-ecological systems framework.

\section{ACKNOWLEDGEMENTS}

Administrative support in project implementation and data collection was provided by project collaborators Marty Chintala, Suzy Avayzian, and Mary Schoell at the U.S. Environmental Protection Agency’s Atlantic Ecology Division; Suzan Bellincampi, Josey Kirkland, and Savannah Lawson at the Mass Audubon Felix Neck Wildlife Sanctuary; and David Grunden at the Martha's Vineyard Shellfish Group. 


\section{REFERENCES}

Agardy M.T. (1993) Accommodating ecotourism in multiple use planning of coastal and marine protected areas. Ocean \& Coastal Management 20, 219-239.

Arkema K.K., Verutes G.M., Wood S.A. et al. (2015) Embedding ecosystem services in coastal planning leads to better outcomes for people and nature. Proceedings of the National Academy of Sciences 112, 7390-7395.

Berkes F. (2009) Evolution of co-management: role of knowledge generation, bridging organizations and social learning. Journal of environmental management 90, 1692-1702.

Berkes F., Folke C., Colding J. (2000) Linking social and ecological systems: management practices and social mechanisms for building resilience. Cambridge University Press.

Bozek C.M. \& Burdick D.M. (2005) Impacts of seawalls on salt marsh plant communities in the Great Bay Estuary, New Hampshire USA. Wetlands Ecology and Management 13, 553-568.

Collins C.M. \& Chambers S.M. (2005) Psychological and situational influences on commuter-transport-mode choice. Environment and behavior 37, 640-661.

Cutroneo L., Massa F., Castellano M. et al. (2014) Technical and public approaches to involve dredging stakeholders and citizens in the development of a port area. Environmental earth sciences 72, 3159-3171.

de Juan S., Gelcich S., Fernandez M. (2017) Integrating stakeholder perceptions and preferences on ecosystem services in the management of coastal areas. Ocean \& Coastal Management 136, 38-48. 
Druschke C.G. \& McGreavy B. (2016) Why rhetoric matters for ecology. Frontiers in Ecology and the Environment 14, 46-52.

Dunlap R.E. \& Van Liere K.D. (1978) The “new environmental paradigm”. The journal of environmental education 9, 10-19.

Gelcich S., Edwards-Jones G., Kaiser M.J. (2005) Importance of Attitudinal Differences among Artisanal Fishers toward Co-Management and Conservation of Marine Resources. Conservation Biology 19, 865-875.

Gittman R.K., Peterson C.H., Currin C.A. et al. (2016) Living shorelines can enhance the nursery role of threatened estuarine habitats. Ecological Applications, 26 249-263.

Gliem J.A. \& Gliem R.R. (2003) Calculating, interpreting, and reporting Cronbach's alpha reliability coefficient for Likert-type scales. Midwest Research-to-Practice Conference in Adult, Continuing, and Community Education.

Guagnano G.A., Stern P.C., Dietz T. (1995) Influences on attitude-behavior relationships a natural experiment with curbside recycling. Environment and behavior 27, 699718.

Hall C.M. (2001) Trends in ocean and coastal tourism: the end of the last frontier? Ocean \& coastal management 44, 601-618.

Haynie A. \& Huntington H. (2016) Strong connections, loose coupling: the influence of the Bering Sea ecosystem on commercial fisheries and subsistence harvests in Alaska. Ecology and Society 21.

Ives C.D. \& Kendal D. (2014) The role of social values in the management of ecological systems. Journal of environmental management 144, 67-72. 
Klain S.C. \& Chan K.M. (2012) Navigating coastal values: participatory mapping of ecosystem services for spatial planning. Ecological economics 82, 104-113.

Klein Y.L., Osleeb J.P., Viola M.R. (2004) Tourism-generated earnings in the coastal zone: a regional analysis. Journal of Coastal Research, 1080-1088.

Le Gentil E. \& Mongruel R. (2015) A systematic review of socio-economic assessments in support of coastal zone management (1992-2011). Journal of environmental management 149, 85-96.

Liu J., Dietz T., Carpenter S.R. et al. (2007) Complexity of coupled human and natural systems. science $\mathbf{3 1 7}, 1513-1516$.

Lotze H.K., Lenihan H.S., Bourque, B.J. et al. (2006) Depletion, degradation, and recovery potential of estuaries and coastal seas. Science 312, 1806-1809.

hMaio G.R. (2003) Ideologies, Values, Attitudes, and Behavior»: 283-308. Hanbook of Social Psychology New York, Academic/Plenum Publishers.

Mascia M.B., Brosius J.P., Dobson T.A. et al. (2003) Conservation and the social sciences. Conservation biology 17, 649-650.

Millennium Ecosystem Assessement. (2005) Ecosystems and human well-being: biodiversity synthesis. World Resources Institute, Washington, DC.

Rao J.N. \& Scott A.J. (1981) The analysis of categorical data from complex sample surveys: chi-squared tests for goodness of fit and independence in two-way tables. Journal of the American Statistical Association 76, 221-230.

Reed M.S. (2008) Stakeholder participation for environmental management: a literature review. Biological conservation 141, 2417-2431. 
Rowe G. \& Frewer L.J. (2005) A typology of public engagement mechanisms. Science, technology \& human values 30, 251-290.

Schubert S.F., Brida J.G., Risso W.A. (2011) The impacts of international tourism demand on economic growth of small economies dependent on tourism. Tourism Management 32, 377-385.

Schwartz S.H. (1992) Universals in the content and structure of values: Theoretical advances and empirical tests in 20 countries. Advances in experimental social psychology 25, 1-65.

Schwartz S.H. (1994) Are There Universal Aspects in the Structure and Content of Human Values? Journal of social issues 50, 19-45.

Schwartz S.H. \& Bilsky W. (1990) Toward a theory of the universal content and structure of values: Extensions and cross-cultural replications. Journal of personality and social psychology $\mathbf{5 8}, 878$.

Sim J. \& Wright C.C. (2005) The kappa statistic in reliability studies: use, interpretation, and sample size requirements. Physical therapy 85, 257.

Spalding M.D., Ruffo S., Lacambra C. et al. (2014) The role of ecosystems in coastal protection: adapting to climate change and coastal hazards. Ocean \& Coastal Management 90, 50-57.

Steg L. \& Vlek C. (2009) Encouraging pro-environmental behaviour: An integrative review and research agenda. Journal of environmental psychology 29, 309-317.

Stern M.J. (2008) Coercion, voluntary compliance and protest: the role of trust and legitimacy in combating local opposition to protected areas. Environmental Conservation 35, 200-210. 
Stern P.C. (2000) New environmental theories: toward a coherent theory of environmentally significant behavior. Journal of social issues 56, 407-424.

Stern P.C., Dietz T., Abel T.D., Guagnano G.A., Kalof L. (1999) A value-belief-norm theory of support for social movements: The case of environmentalism. Human ecology review $\mathbf{6}, 81$.

Stern P.C., Dietz T., Kalof L. (1993) Value orientations, gender, and environmental concern. Environment and behavior 25, 322-348.

US Department of Commerce. (2015) Income and Earnings Summary by Selected Characteristics: 2014 and 2015.

Vitousek P.M., Mooney H.A., Lubchenco J., Melillo J.M. (1997) Human domination of Earth's ecosystems. Science 277, 494-499.

Wilsdon J. \& Willis R. (2004) See-through science: Why public engagement needs to move upstream. Demos, New York City, NY. 


\section{TABLES}

Table 1. List of variables including factors, reliability of latent factors using Cronbach's alpha (Sim and Wright 2005), descriptions, and data type.

\begin{tabular}{|c|c|c|c|c|}
\hline Variable & Factor & $\begin{array}{l}\text { Reliability } \\
\text { (Cronbach's } \\
\text { alpha) }\end{array}$ & Description & Data Type \\
\hline \multirow[t]{6}{*}{ Demographics } & Resident vs. Tourist & - & $\begin{array}{l}\text { Whether respondent is visiting or living on island at } \\
\text { the time of interview; seasonal residents categorized } \\
\text { as residents }\end{array}$ & Categorical \\
\hline & Pond Use & - & $\begin{array}{l}\text { Most frequent activities within or around pond that } \\
\text { serves as restoration project site }\end{array}$ & Categorical \\
\hline & Gender & - & - & Binary; (Male, Female) \\
\hline & Age & - & - & Continuous \\
\hline & Education & - & Highest obtained education degree & $\begin{array}{l}\text { 5-point Likert-type scale; 'less } \\
\text { than high school' - 'graduate or } \\
\text { professional degree' }\end{array}$ \\
\hline & Income & - & Household annual income & $\begin{array}{c}\text { 5-point Likert-type scale; 'less } \\
\text { than } \$ 25,000 \text { ' - '\$200,000 or } \\
\text { more' }\end{array}$ \\
\hline \multirow[t]{4}{*}{ Values } & Altruistic Values & 0.701 & $\begin{array}{c}\text { Importance of the follow items as 'guiding principles' } \\
\text { in the life of respondent: (1) social justice, (2) } \\
\text { equality, (3) world peace }\end{array}$ & 5-point Likert-type scale \\
\hline & Biospheric Values & 0.850 & $\begin{array}{l}\text { Importance of the follow items as 'guiding principles' } \\
\text { in the life of respondent: (1) unity with nature, (2) } \\
\text { respecting earth, (3) preserving nature }\end{array}$ & 5-point Likert-type scale \\
\hline & Egoistic Values & 0.502 & $\begin{array}{l}\text { Importance of the follow items as 'guiding principles' } \\
\text { in the life of respondent: (1) influential, (2) wealth, } \\
\text { (3) authority }\end{array}$ & 5-point Likert-type scale \\
\hline & Traditional Values & 0.701 & $\begin{array}{l}\text { Importance of the follow items as 'guiding principles' } \\
\text { in the life of respondent: (1) self-discipline, (2) } \\
\text { family security, (3) honoring elders }\end{array}$ & 5-point Likert-type scale \\
\hline \multirow[t]{2}{*}{ Beliefs } & NEP Score & 0.830 & $\begin{array}{l}\text { Score on dichotomous scale representing } \\
\text { endorsement of a 'new ecological paradigm' vs. the } \\
\text { 'dominant social paradigm' (Dunlap et al. 2005) }\end{array}$ & $\begin{array}{c}\text { 7-35 Score; } 7 \text { (strongest } \\
\text { endorsement of dominant social } \\
\text { paradigm); } 35 \text { (strongest } \\
\text { endorsement of new ecological } \\
\text { paradigm) }\end{array}$ \\
\hline & $\begin{array}{c}\text { Awareness of } \\
\text { Consequences (AC) }\end{array}$ & 0.779 & $\begin{array}{l}\text { Perceived threat of degraded Martha's Vineyard } \\
\text { coastal ponds to: (1) local plants and animals, }(2) \\
\text { them and their family, (3) the local community }\end{array}$ & 5-point Likert-type scale \\
\hline Personal Norms & $\begin{array}{l}\text { Environmental } \\
\text { Behavior Norms }\end{array}$ & 0.774 & $\begin{array}{l}\text { (1) Effort spent staying informed on ecological } \\
\text { conservation and restoration issues, ( } 2 \text { ) extent that } \\
\text { ecological considerations drive daily behavior }\end{array}$ & 5-point Likert-type scale \\
\hline $\begin{array}{l}\text { Project Understanding } \\
\text { (PU) }\end{array}$ & PU Score & - & $\begin{array}{l}\text { Score representing extent of respondent's } \\
\text { understanding of the restoration project, project } \\
\text { design, and project goals }\end{array}$ & $\begin{array}{l}\text { 1-4 Score; } 3 \text { binary (Yes, No) } \\
\text { questions on project aspect } \\
\text { understanding }\end{array}$ \\
\hline $\begin{array}{c}\text { Definitions of } \\
\text { Restoration Success }\end{array}$ & $\begin{array}{l}\text { Definition of Success } \\
\text { (DOS) }\end{array}$ & - & $\begin{array}{l}\text { How respondent describes successful restoration of } \\
\text { coastal pond ecosystems }\end{array}$ & Qualitative (Open-ended) \\
\hline $\begin{array}{l}\text { Restoration Strategy } \\
\text { Preference }\end{array}$ & Strategy Preference & - & $\begin{array}{l}\text { Prioritization of specific restoration strategies in } \\
\text { order to achieve successful coastal pond ecosystem } \\
\text { restoration success }\end{array}$ & $\begin{array}{l}\text { 1-3 Ranking; top } 3 \text { priority } \\
\text { strategies ranked }\end{array}$ \\
\hline Project Support & Project Support & - & $\begin{array}{c}\text { Extent of support or opposition of Martha's Vineyard } \\
\text { living shoreline restoration project }\end{array}$ & 5-point Likert-type scale \\
\hline
\end{tabular}


Table 2. Value-Belief-Norm (VBN) variable mean scores and measures of dispersion.

\begin{tabular}{|c|c|c|c|c|c|c|}
\hline \multirow{2}{*}{ Variable Category } & \multirow{2}{*}{ Variable } & \multirow{2}{*}{ Scale } & \multicolumn{4}{|c|}{ Score } \\
\hline & & & Mean & $\mathrm{SD}$ & Min & Max \\
\hline \multirow[t]{4}{*}{ Values } & Altruism & 1 (weak) - 5 (strong) & 4.22 & 0.71 & 1.67 & 5.00 \\
\hline & Biospherism & 1 (weak) - 5 (strong) & 4.33 & 0.60 & 2.33 & 5.00 \\
\hline & Egoism & 1 (weak) - 5 (strong) & 3.04 & 0.62 & 1.67 & 4.33 \\
\hline & Traditionalism & 1 (weak) - 5 (strong) & 4.30 & 0.55 & 3.00 & 5.00 \\
\hline \multirow[t]{4}{*}{$\begin{array}{l}\text { Environmental } \\
\text { Concern }\end{array}$} & Beliefs & $\begin{array}{l}7 \text { (DSP endorsement) - } 35 \text { (NEP } \\
\text { endorsement) }\end{array}$ & 27.92 & 4.62 & 14.00 & 35.00 \\
\hline & $\begin{array}{l}\text { Consequences For Plants \& } \\
\text { Animals }\end{array}$ & 1 (weak) - 5 (strong) & 4.56 & 0.73 & 2.00 & 5.00 \\
\hline & Consequences For You \& Family & 1 (weak) - 5 (strong) & 3.57 & 1.01 & 1.00 & 5.00 \\
\hline & $\begin{array}{l}\text { Consequences For Local } \\
\text { Community }\end{array}$ & 1 (weak) - 5 (strong) & 4.37 & 0.74 & 2.00 & 5.00 \\
\hline \multirow[t]{2}{*}{ Personal Norms } & Try to Stay Informed & 1 (weak) - 5 (strong) & 3.44 & 0.92 & 1.00 & 5.00 \\
\hline & $\begin{array}{l}\text { Environmental Consequence } \\
\text { Guides Behavior }\end{array}$ & 1 (weak) - 5 (strong) & 3.88 & 0.81 & 1.00 & 5.00 \\
\hline
\end{tabular}


Table 3. Results from independent-samples t-tests of coastal management preferences by Martha's Vineyard residents (R) and tourists (T), and shellfishers (S) and non-shellfishers (NS).

\begin{tabular}{|c|c|c|c|c|c|c|}
\hline & \multicolumn{3}{|c|}{ Residency } & \multicolumn{3}{|c|}{ Shellfishing } \\
\hline & $\mathrm{F}$ & p-value & $\begin{array}{l}\text { Pairwise } \\
\text { Comparison }\end{array}$ & $\mathrm{F}$ & p-value & $\begin{array}{l}\text { Pairwise } \\
\text { Comparison }\end{array}$ \\
\hline $\begin{array}{l}\text { Habitat } \\
\text { Restoration }\end{array}$ & $0.77_{81,1}$ & 0.022 & $\mathrm{R}<\mathrm{T}$ & $0.35_{81,1}$ & 0.012 & $\mathrm{~S}<\mathrm{NS}$ \\
\hline Bioremediation & $2.81_{81,1}$ & 0.987 & - & $5.00_{81,1}$ & 0.537 & - \\
\hline $\begin{array}{l}\text { Septic \& } \\
\text { Sewer Regulation }\end{array}$ & $0.11_{81,1}$ & 0.819 & - & $2.93_{81,1}$ & 0.022 & $\mathrm{~S}>\mathrm{NS}$ \\
\hline $\begin{array}{l}\text { Development } \\
\text { Restrictions }\end{array}$ & $3.22_{81,1}$ & 0.438 & - & $2.68_{81,1}$ & 0.674 & - \\
\hline $\begin{array}{l}\text { Dredging } \\
\text { \& Breaching }\end{array}$ & $37.66_{81,1}$ & 0.002 & $\mathrm{R}>\mathrm{T}$ & $2.92_{81,1}$ & 0.149 & - \\
\hline
\end{tabular}




\section{FIGURES}

a.)

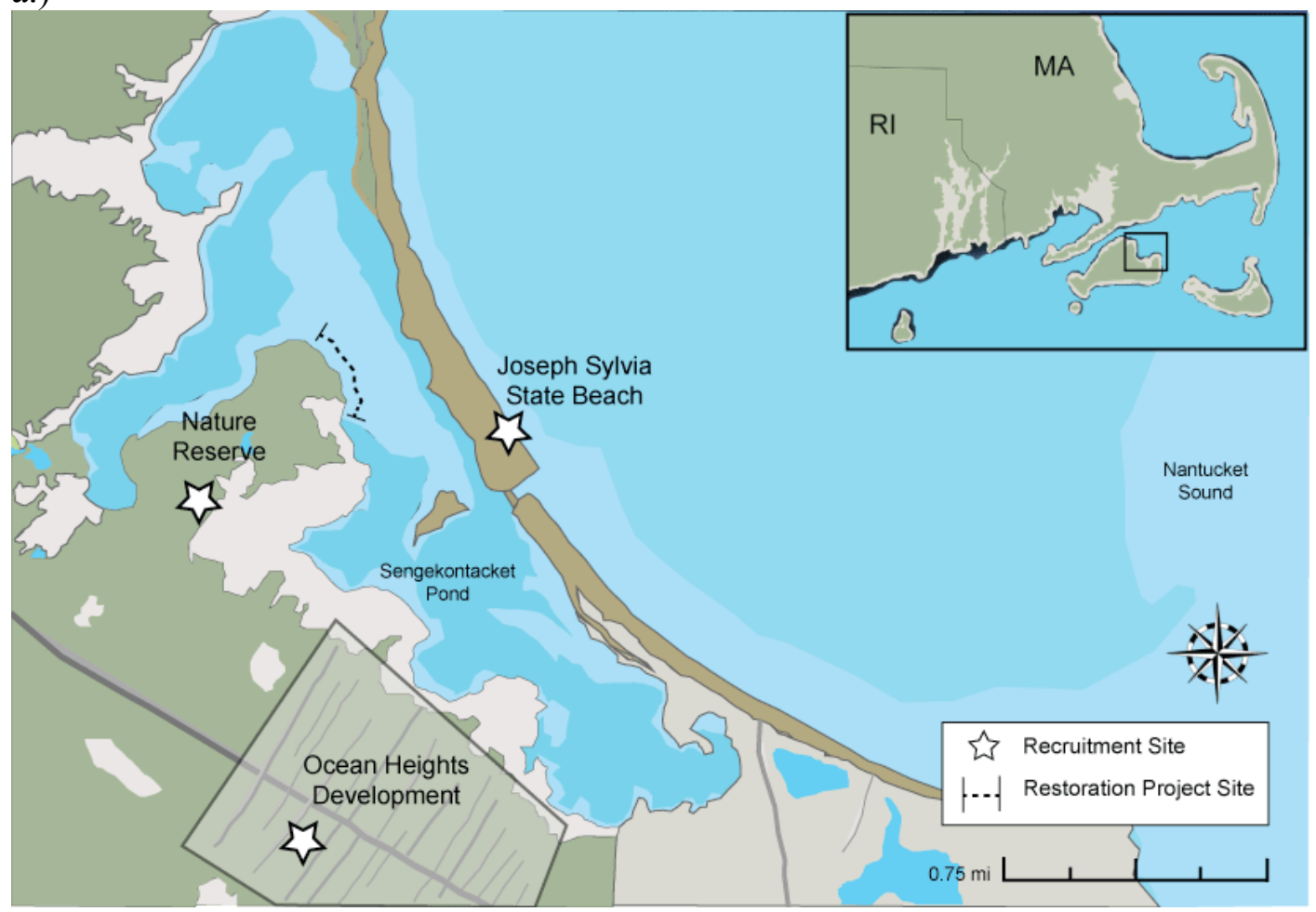

b.)

c.)
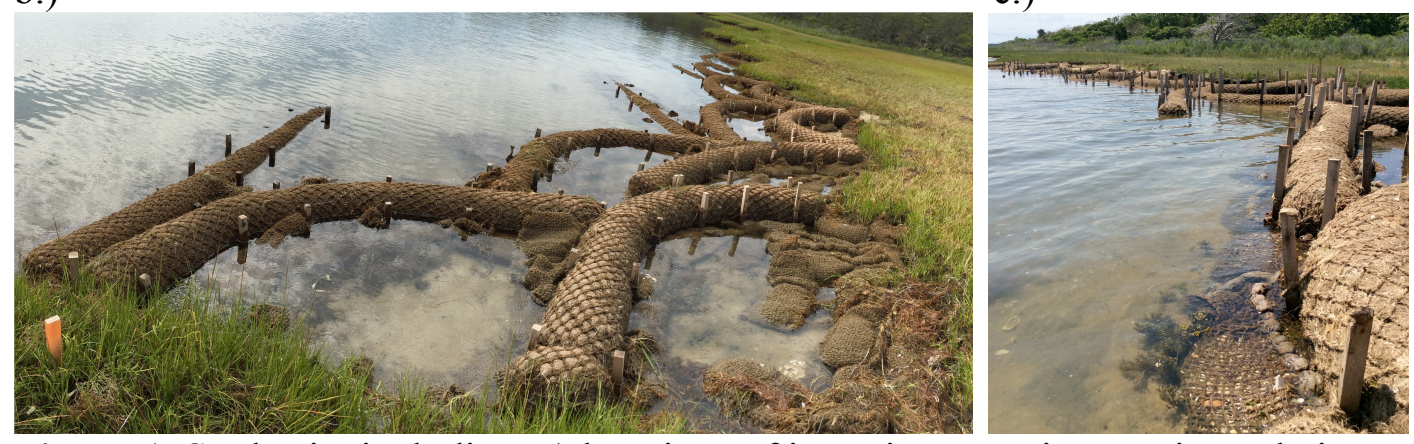

Figure 1. Study site including a.) locations of interview recruitment sites relative to the living shoreline restoration project site, b.) living shoreline restoration project, and c.) detail of living shoreline design using coconut fiber logs and bags of oyster shell as a biodegradable shoreline stabilization and salt marsh habitat facilitation structure. 


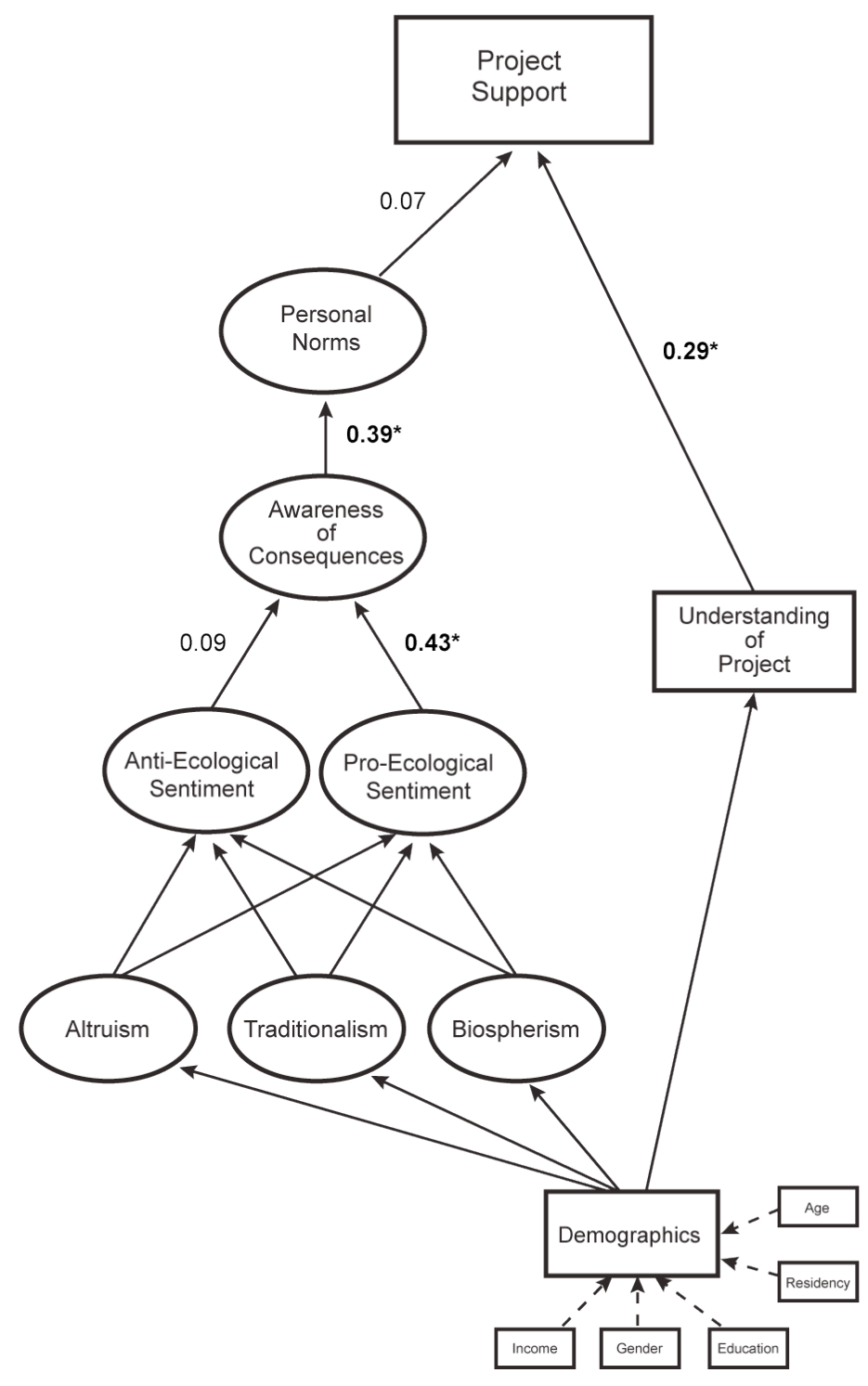

Figure 2. Structural equation model (SEM) of restoration project support predicted by values-beliefs-norms (VBN) attitudinal variables and an individual's level of understanding of the project. Variables represented by squares are state variables and those in circles are latent variables. Demographic variables are visually represented as a single state variable to simplify the figure, but predictive pathways from all five variables were tested. Values on pathways are regression coefficients, (' $*$ ' indicates statistical significance at the $\mathrm{p}<0.05$ level). 


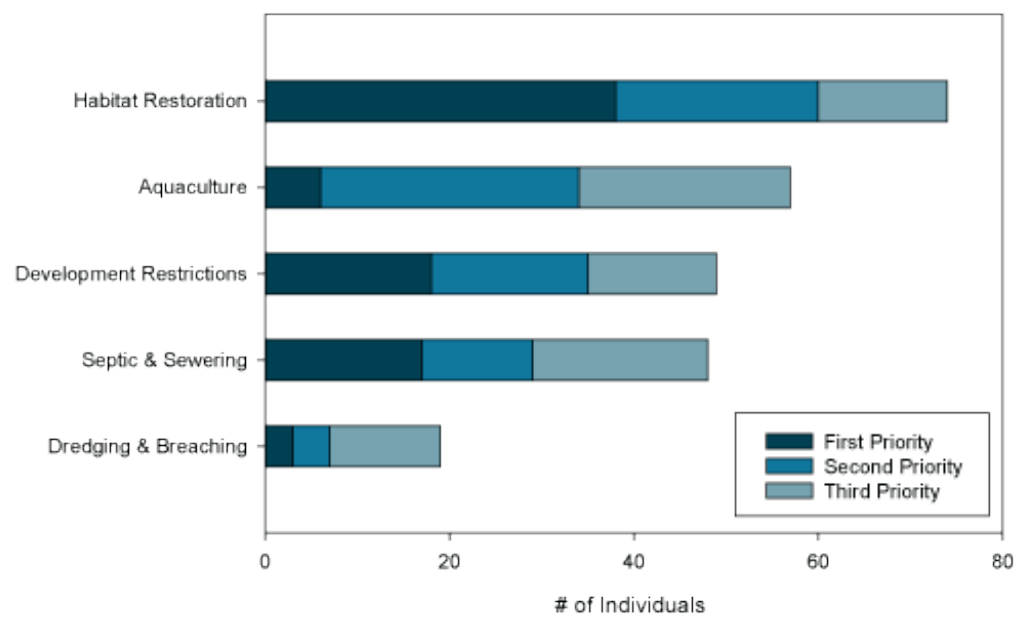

Figure 3. Study participants' prioritization of strategies for the conservation and management of coastal salt ponds on Martha's Vineyard. 


\section{SUPPORTING INFORMATION}

\section{APPENDIX S1}

\section{VALUES-BELIEFS-NORMS THEORY}

The structure of the questionnaire used in interviews follows a modified valuesbeliefs-norms (VBN) framework. The VBN model marries three social-psychological theories to assess the hierarchical role of personal values, environmental beliefs and moral norms as foundational components of environment-relevant attitudes and behavior (Stern 2000).

Personal values are characterized according to the structure originally developed in S. H. Schwartz and Wolfgang Bilsky's Theory of Basic Human Values (Schwartz \& Bilsky 1987; Schwartz \& Bilsky 1990; Schwartz 1992, 1994), and adapted by Stern and colleagues (Stern et al. 1993). This adaptation was the re-organization of Schwartz's values into the values 'orientations' already described. More recent works (Dietz et al. 2005; Bidwell 2013; Hicks et al. 2015) have identified strong links between values of 'traditionalism' (e.g. conformity, security) and environment-relevant attitudes. The present study uses Schwartz value items representing altruistic, egoistic, biospheric, and traditionalism orientations to measure the underlying value structures of interview participants.

The VBN characterization of environmental beliefs stems from the New Ecological Paradigm (NEP) (Dunlap \& Van Liere 1978; Dunlap et al. 2000; Dunlap et al. 2005). The NEP describes a paradigm shift in environmental thinking believed to have occurred in conjunction with the rise of environmentalism at the end of the 20th century. This shift 
represented a movement away from the idea that a combination of technological advancement and nature's resilience would allow human societies to expand without repercussion; the 'Dominant Social Paradigm' (DSP), and towards a mode of thinking that emphasized the limitations of natural resources and society's ability to disrupt a 'delicate balance' in the world's ecosystems (the 'New Ecological Paradigm'). Early work by Dunlap and colleagues led to the development of the 'NEP scale', a survey instrument used to measure an individual's endorsement of either the DSP or the NEP. Subsequent studies have led to three revisions of the NEP scale and its solidification as the most widely used measurement of environmental beliefs (Dunlap 2008). A revised, shortened version of the NEP scale (Whitfield et al. 1999) is used in the present study.

Finally, the VBN model incorporates the role of moral norms based on theory described by S.H. Schwartz's Normative Influence Model (Schwartz 1973). Broadly, a norm can be injunctive (i.e. involve behavior perceived as something that 'ought' to be done or not done), or descriptive (i.e. involve behavior perceived as typically done or not done) (Cialdini 2003). Moral norms are described as the result of anticipated repercussions of specific courses of action, and are believed to play a crucial role in decision-making either consciously or subconsciously. A subconscious influence on behavior is difficult to document empirically. However, if present, environment-relevant moral norms are shown to be called to attention, or 'activated' in the mind of an individual in response to a condition that is more easily measured: an awareness of consequences (AC) (see Dunlap \& Van Liere 1978; Stern et al. 1985; Nordlund \& Garvill 2003; Matthies et al. 2012). This suggests that pro-environmental behaviors are 
elicited in individuals who believe that environmental problems pose significant threats to what they value.

With the marriage of these three theories, the Values-Beliefs-Norms (VBN) model describes a hierarchical causation of environmental behavior. Causal flow starts from foundational elements (i.e. personal values), and moves outward to perspectives of the relationship between humans and nature, awareness of threats, and finally the influence of personal moral norms. In the present study, this framework is modified to include contextual factors and qualitative components expected to inform the relationship between VBN variables and ultimate support for coastal management strategies. An individual's level of understanding of the living shoreline restoration project was measured using a three-part question. This question gauged understanding of (1) project goals, (2) project design, and lastly (3) confidence - which acted as a check on the first two answers. An open-response question on how an individual defined 'successful' coastal restoration provided qualitative information on preferences for conservation outcomes, and how this relates to prioritization of coastal management strategies. 


\section{Literature Cited}

Bidwell D. (2013) The role of values in public beliefs and attitudes towards commercial wind energy. Energy Policy 58, 189-199.

Cialdini R.B. (2003) Crafting normative messages to protect the environment. Current directions in psychological science 12, 105-109.

Dietz T., Fitzgerald A., Shwom R. (2005) Environmental values. Annual Review of Environmental Resources 30, 335-372.

Dunlap R.E. (2008) The new environmental paradigm scale: From marginality to worldwide use. The journal of environmental education 40, 3-18.

Dunlap R.E., Van Liere K., Mertig A., Jones R.E. (2005) Measuring Endorsement of the New Ecological Paradigm: A Revised NEP Scale. The Earthscan Reader in Environmental Values, Earthscan, London.

Dunlap R.E. \& Van Liere K.D. (1978) The "new environmental paradigm". The journal of environmental education 9, 10-19.

Dunlap R.E., Van Liere K.D., Mertig A.G., Jones R.E. (2000) New trends in measuring environmental attitudes: measuring endorsement of the new ecological paradigm: a revised NEP scale. Journal of social issues 56, 425-442.

Hicks C.C., Cinner J.E., Stoeckl N., McClanahan T.R. (2015) Linking ecosystem services and human-values theory. Conservation Biology 29, 1471-1480.

Matthies E., Selge S., Klöckner C.A. (2012) The role of parental behaviour for the development of behaviour specific environmental norms-The example of recycling and re-use behaviour. Journal of Environmental Psychology 32, 277284. 
Nordlund A.M. \& Garvill J. (2003) Effects of values, problem awareness, and personal norm on willingness to reduce personal car use. Journal of environmental psychology 23, 339-347.

Schwartz S.H. (1973) Normative explanations of helping behavior: A critique, proposal, and empirical test. Journal of Experimental Social Psychology 9, 349-364.

Schwartz S.H. (1992) Universals in the content and structure of values: Theoretical advances and empirical tests in 20 countries. Advances in experimental social psychology 25, 1-65.

Schwartz S.H. (1994) Are There Universal Aspects in the Structure and Content of Human Values? Journal of social issues 50, 19-45.

Schwartz S.H. \& Bilsky W. (1987) Toward a universal psychological structure of human values. Journal of Personality and Social Psychology 53, 550-562.

Schwartz S.H. \& Bilsky W. (1990) Toward a theory of the universal content and structure of values: Extensions and cross-cultural replications. Journal of personality and social psychology 58, 878 .

Stern P.C. (2000) New environmental theories: toward a coherent theory of environmentally significant behavior. Journal of social issues 56, 407-424.

Stern P.C., Dietz T., Black J.S. (1985) Support for environmental protection: The role of moral norms. Population and Environment 8, 204-222.

Stern P.C., Dietz T., Kalof L. (1993) Value orientations, gender, and environmental concern. Environment and behavior 25, 322-348. 
Whitfield S., Dietz T., Rosa E. (1999) Environmental values, risk perception and support for nuclear technology. Human Ecology Research Group, George Mason University, Fairfax, Virginia. 


\section{APPENDIX S2}

\section{STRUCTURAL EQUATION MODELING}

A covariance-based structural equation model (CB-SEM) was designed in accordance with relationships suggested by VBN theory (Stern et al. 1999). Available model modifications produced a parsimonious model that did not achieve minimum standards in measures of global goodness-of-fit (CFI $>0.900$, RMSEA $<0.05)$. Additionally, the data set did not meet the CB-SEM assumption of multivariate normality. A partial least squares regression method of estimation (partial least squares structural equation modeling; PLS-SEM) was conducted to address these challenges. In contrast to the goal of CB-SEM (matching the covariance matrix of the observed data set to that of the theoretical matrix indicated by the relationships in the model), PLS-SEM approaches focus on maximizing explained variance of endogenous variables. Despite this difference in statistical methodology, PLS-SEM is considered an acceptable alternative to CB-SEM for theory-testing (Hair et al. 2011). Particularly in cases where data collection is driven by theory but fails to meet requirements for minimum sample size, maximum numbers of variables (model complexity), and multivariate normal distributions, PLS-SEM results can act as a surrogate for those of CB-SEM.

The PLS-SEM path model structure was identical to that used in CB-SEM. The PLSSEM analysis was conducted in SmartPLS analytical software. Measurement models of latent variables and the final structural model were evaluated based on guidelines set forth in the literature (see Table 3 in Hair et al. 2011). Minimum standards of internal consistency, indicator reliability, and convergent and discriminant validity were met by all measurement models of latent variables used in the final structural model, except for 
the latent construct measuring 'egoistic' values (Tables S2a-d). Low composite reliability, average variance extracted (AVE), and indicator loadings suggested that, in the case of this study, the three observed variables measuring an individual's valuation of (1) being influential, (2) having wealth, and (3) having authority, did not adequately represent an underlying construct of 'egoism'. These problems mirrored some of those occurring in CB-SEM analyses (low squared multiple correlations of egoism indicator variables). For these reasons, the 'egoism' latent construct was removed from the model. Multi-model analysis was used to compare the strength of the VBN pathway in predicting project support against that of project understanding (PU) (Figures S2a \& S2b). Statistical significance of estimated PLS-SEM path coefficients was tested using Tstatistics generated using bootstrapping methods (Hair Jr \& Hult 2016). 


\section{Literature Cited}

Hair J.F., Ringle C.M., Sarstedt M. (2011) PLS-SEM: Indeed a silver bullet. Journal of Marketing theory and Practice 19, 139-152.

Hair Jr J.F. \& Hult G.T.M. (2016) A primer on partial least squares structural equation modeling (PLS-SEM). Sage Publications.

Stern P.C., Dietz T., Abel T.D., Guagnano G.A., Kalof L. (1999) A value-belief-norm theory of support for social movements: The case of environmentalism. Human ecology review $\mathbf{6}, 81$. 


\section{Appendix S2 Tables}

Table S2a. PLS-SEM path model criteria showing internal consistency reliability and convergent validity.

\begin{tabular}{lccc}
\hline & $\begin{array}{c}\text { Cronbach' } \\
\text { s Alpha }\end{array}$ & $\begin{array}{c}\text { Composite } \\
\text { Reliability }\end{array}$ & $\begin{array}{c}\text { Average Variance Extracted } \\
\text { (AVE) }\end{array}$ \\
\hline Age & 1 & 1 & 1 \\
Altruism & 0.584 & 0.777 & 0.541 \\
Anthropocentric Management Goals & 1 & 1 & 1 \\
Anti-NEP & 0.762 & 0.862 & 0.676 \\
Biospherism & 0.86 & 0.915 & 0.783 \\
Education & 1 & 1 & 1 \\
Egoism & 0.546 & 0.586 & 0.391 \\
Environmental Beliefs & 0.775 & 0.872 & 0.699 \\
Environmental Citizenship Behavior & 1 & 1 & 1 \\
FN Visitation & 1 & 1 & 1 \\
Personal Environmental Norms & 0.813 & 0.915 & 0.843 \\
Pro-NEP & 0.87 & 0.911 & 0.719 \\
Project Support & 1 & 1 & 1 \\
Resident Status_ & 1 & 0.835 & 1 \\
Traditionalism & 0.699 & 1 & 0.63 \\
Understanding of Project & 1 & 1 & 1 \\
\hline & & 1 & 1 \\
\hline
\end{tabular}


Table S2b. PLS-SEM path model criteria showing indicator reliability.

\begin{tabular}{|c|c|c|c|c|c|c|c|c|}
\hline & Altruism & $\begin{array}{l}\text { Anti- } \\
\text { NEP }\end{array}$ & Biospherism & Egoism & $\begin{array}{c}\text { Environmental } \\
\text { Beliefs }\end{array}$ & $\begin{array}{c}\text { Personal Environmental } \\
\text { Norms }\end{array}$ & $\begin{array}{l}\text { Pro- } \\
\text { NEP }\end{array}$ & Traditionalism \\
\hline AC_Community & & & & & 0.957 & & & \\
\hline AC_Family & & & & & 0.636 & & & \\
\hline AC_Plant_Animal & & & & & 0.881 & & & \\
\hline EnvCit_Norm_Guided & & & & & & 0.923 & & \\
\hline EnvCit_Norm_Informed & & & & & & 0.913 & & \\
\hline NEP_Anti_1 & & 0.832 & & & & & & \\
\hline NEP_Anti_2 & & 0.791 & & & & & & \\
\hline NEP_Anti_3 & & 0.843 & & & & & & \\
\hline NEP_Pro_1 & & & & & & & 0.814 & \\
\hline NEP_Pro_2 2 & & & & & & & 0.773 & \\
\hline NEP_Pro_3 & & & & & & & 0.926 & \\
\hline NEP_Pro_4 & & & & & & & 0.871 & \\
\hline Value_A1 & 0.726 & & & & & & & \\
\hline Value_A2 & 0.626 & & & & & & & \\
\hline Value_A3 & 0.84 & & & & & & & \\
\hline Value_B1 & & & 0.803 & & & & & \\
\hline Value_B2 & & & 0.941 & & & & & \\
\hline Value_B3 & & & 0.904 & & & & & \\
\hline Value_E1 & & & & 0.992 & & & & \\
\hline Value_E2 & & & & 0.332 & & & & \\
\hline Value_E3 & & & & 0.282 & & & & \\
\hline Value_T1 & & & & & & & & 0.684 \\
\hline Value_T2 & & & & & & & & 0.788 \\
\hline Value_T3 & & & & & & & & 0.895 \\
\hline
\end{tabular}


Table S2c. Average variance explained (AVE) of each latent construct in the PLS-SEM path model showing discriminant validity based on Fornell-Larcker criterion.

\begin{tabular}{|c|c|c|c|c|c|c|c|c|c|c|}
\hline $\begin{array}{l}\text { Average Variance } \\
\text { Extracted (AVE) }\end{array}$ & & Altruism & $\begin{array}{l}\text { Anti- } \\
\text { NEP }\end{array}$ & Biospherism & Egoism & $\begin{array}{l}\text { Environmental } \\
\text { Beliefs }\end{array}$ & $\begin{array}{c}\text { Personal } \\
\text { Environmental } \\
\quad \text { Norms }\end{array}$ & $\begin{array}{l}\text { Pro- } \\
\text { NEP }\end{array}$ & $\begin{array}{l}\text { Project } \\
\text { Support }\end{array}$ & Traditionalism \\
\hline 0.541 & Altruism & 0.736 & & & & & & & & \\
\hline 0.676 & Anti-NEP & 0.375 & 0.822 & & & & & & & \\
\hline 0.783 & Biospherism & 0.78 & 0.429 & 0.885 & & & & & & \\
\hline 0.391 & Egoism & 0.06 & 0.056 & 0.082 & 0.626 & & & & & \\
\hline 0.699 & Environmental Beliefs & 0.488 & 0.387 & 0.545 & 0.119 & 0.836 & & & & \\
\hline 0.843 & $\begin{array}{l}\text { Personal Environmental } \\
\text { Norms }\end{array}$ & 0.416 & 0.331 & 0.502 & -0.123 & 0.453 & 0.918 & & & \\
\hline 0.719 & Pro-NEP & 0.65 & 0.5 & 0.686 & 0.079 & 0.447 & 0.306 & 0.848 & & \\
\hline 0.63 & Traditionalism & 0.231 & $\overline{0.001}$ & 0.413 & 0.158 & 0.314 & 0.059 & 0.16 & -0.091 & 0.794 \\
\hline
\end{tabular}


Table S2d. Loadings of each indicator in the PLS-SEM path model showing discriminant validity.

\begin{tabular}{|c|c|c|c|c|c|c|c|c|c|c|c|c|c|c|c|c|}
\hline & Age & $\begin{array}{c}\text { Altrui } \\
\mathrm{sm}\end{array}$ & $\begin{array}{c}\text { Anthropoce } \\
\text { ntric } \\
\text { Managemen } \\
\text { t Goals }\end{array}$ & $\begin{array}{c}\text { Ant } \\
\text { i- } \\
\text { NE } \\
\text { P } \\
\end{array}$ & $\begin{array}{c}\text { Biospher } \\
\text { ism }\end{array}$ & $\begin{array}{c}\text { Educat } \\
\text { ion }\end{array}$ & 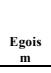 & $\begin{array}{l}\text { Environme } \\
\text { ntal Beliefs }\end{array}$ & $\begin{array}{c}\text { Environme } \\
\text { ntal } \\
\text { Citizenship } \\
\text { Behavior } \\
\end{array}$ & $\begin{array}{c}\mathrm{FN} \\
\text { Visitati } \\
\text { on }\end{array}$ & $\begin{array}{c}\text { Personal } \\
\text { Environme } \\
\text { ntal Norms }\end{array}$ & $\begin{array}{c}\text { Pro } \\
- \\
\mathrm{NE} \\
\mathrm{P} \\
\end{array}$ & $\begin{array}{c}\text { Proje } \\
\text { ct } \\
\text { Supp } \\
\text { ort }\end{array}$ & $\begin{array}{c}\text { Resid } \\
\text { ent } \\
\text { Status } \\
\end{array}$ & $\begin{array}{c}\text { Traditiona } \\
\text { lism }\end{array}$ & $\begin{array}{c}\text { Understan } \\
\text { ding of } \\
\text { Project }\end{array}$ \\
\hline AC_Community & $\begin{array}{l}0.4 \\
05\end{array}$ & 0.468 & 0.237 & $\begin{array}{l}0.3 \\
94\end{array}$ & 0.534 & -0.063 & 0.099 & 0.957 & 0.505 & -0.054 & 0.418 & $\begin{array}{l}0.4 \\
36\end{array}$ & 0.186 & -0.012 & 0.266 & -0.164 \\
\hline AC_Family & $\begin{array}{l}0.3 \\
53\end{array}$ & 0.199 & 0.223 & $\begin{array}{l}0.3 \\
39\end{array}$ & 0.255 & 0.061 & 0.061 & 0.636 & 0.369 & -0.15 & 0.212 & $\begin{array}{l}0.0 \\
98\end{array}$ & 0.082 & -0.154 & 0.145 & 0.01 \\
\hline AC_Plant_Animal & $\begin{array}{l}0.2 \\
72\end{array}$ & 0.5 & 0.218 & $\begin{array}{l}0.2 \\
56\end{array}$ & 0.525 & -0.106 & 0.131 & 0.881 & 0.372 & -0.12 & 0.464 & $\begin{array}{l}0.5 \\
04\end{array}$ & 0.211 & -0.022 & 0.349 & -0.257 \\
\hline Age & 1 & 0.358 & 0.005 & $\begin{array}{l}0.2 \\
8\end{array}$ & 0.432 & 0.077 & 0.061 & 0.403 & 0.278 & -0.087 & 0.21 & $\begin{array}{l}0.2 \\
99\end{array}$ & -0.164 & -0.072 & 0.445 & -0.15 \\
\hline Dos_Eco_Social & $\begin{array}{l}0.0 \\
05\end{array}$ & 0.022 & 1 & $\begin{array}{l}0.2 \\
32\end{array}$ & 0.082 & -0.07 & 0.042 & 0.266 & 0.025 & -0.273 & 0.234 & $\begin{array}{l}0.0 \\
87\end{array}$ & -0.15 & -0.381 & -0.026 & -0.233 \\
\hline Education & $\begin{array}{l}0.0 \\
77\end{array}$ & -0.266 & -0.07 & $\begin{array}{l}0.2 \\
72\end{array}$ & -0.441 & 1 & 0.118 & -0.058 & -0.187 & 0.106 & -0.193 & $\begin{array}{l}0.3 \\
81\end{array}$ & -0.182 & 0.098 & 0.093 & 0.085 \\
\hline $\begin{array}{l}\text { EnvCit_Norm_Gu } \\
\text { ided }\end{array}$ & 0.2 & 0.45 & 0.221 & $\begin{array}{l}0.3 \\
09\end{array}$ & 0.46 & -0.146 & 0.112 & 0.429 & 0.476 & -0.008 & 0.923 & $\begin{array}{l}0.2 \\
7\end{array}$ & -0.028 & -0.189 & 0.102 & 0.004 \\
\hline $\begin{array}{l}\text { EnvCit_Norm_Inf } \\
\text { ormed }\end{array}$ & $\begin{array}{l}0.1 \\
85\end{array}$ & 0.31 & 0.207 & $\begin{array}{l}0.2 \\
99\end{array}$ & 0.462 & -0.209 & 0.115 & 0.401 & 0.441 & -0.196 & 0.913 & $\begin{array}{l}0.2 \\
92\end{array}$ & -0.043 & -0.211 & 0.004 & 0.004 \\
\hline EnvCit_Score & $\begin{array}{l}0.2 \\
78\end{array}$ & 0.42 & 0.025 & $\begin{array}{l}0.2 \\
87\end{array}$ & 0.506 & -0.187 & 0.079 & 0.497 & 1 & 0.071 & 0.5 & $\begin{array}{l}0.2 \\
45\end{array}$ & 0.158 & -0.036 & 0.107 & -0.118 \\
\hline NEP_Anti_1 & $\begin{array}{l}0.2 \\
65\end{array}$ & 0.27 & 0.188 & $\begin{array}{l}0.8 \\
32\end{array}$ & 0.428 & -0.229 & 0.053 & 0.331 & 0.288 & 0.034 & 0.311 & $\begin{array}{l}0.4 \\
09\end{array}$ & 0.039 & 0.036 & 0.173 & -0.091 \\
\hline NEP_Anti_2 & $\begin{array}{l}0.1 \\
46\end{array}$ & 0.461 & 0.179 & $\begin{array}{l}0.7 \\
91\end{array}$ & 0.294 & -0.229 & 0.021 & 0.308 & 0.243 & -0.107 & 0.172 & $\begin{array}{l}0.4 \\
47\end{array}$ & 0.196 & -0.042 & -0.072 & 0.041 \\
\hline NEP_Anti_3 & $\begin{array}{l}0.2 \\
63\end{array}$ & 0.225 & 0.205 & $\begin{array}{l}0.8 \\
43\end{array}$ & 0.326 & -0.216 & 0.059 & 0.315 & 0.177 & 0.036 & 0.317 & $\begin{array}{l}0.3 \\
86\end{array}$ & 0.122 & 0.055 & -0.123 & 0.019 \\
\hline NEP_Pro_1 & $\begin{array}{l}0.3 \\
27\end{array}$ & 0.472 & 0.142 & $\begin{array}{l}0.3 \\
47\end{array}$ & 0.493 & -0.165 & -0.09 & 0.505 & 0.256 & 0.2 & 0.345 & $\begin{array}{l}0.8 \\
14\end{array}$ & 0.095 & 0.156 & 0.073 & -0.062 \\
\hline NEP_Pro_2 & $\begin{array}{l}0.2 \\
18\end{array}$ & 0.475 & 0.04 & $\begin{array}{l}0.2 \\
53\end{array}$ & 0.539 & -0.292 & 0.149 & 0.176 & 0.12 & 0.023 & 0.168 & $\begin{array}{l}0.7 \\
73\end{array}$ & 0.272 & 0.101 & 0.136 & -0.012 \\
\hline NEP_Pro_3 & $\begin{array}{l}0.2 \\
31\end{array}$ & 0.6 & 0.01 & $\begin{array}{l}0.4 \\
69\end{array}$ & 0.636 & -0.461 & 0.1 & 0.31 & 0.229 & 0.162 & 0.221 & $\begin{array}{l}0.9 \\
26\end{array}$ & 0.281 & 0.252 & 0.151 & -0.066 \\
\hline NEP_Pro_4 & $\begin{array}{l}0.2 \\
38\end{array}$ & 0.634 & 0.093 & $\begin{array}{l}0.5 \\
64\end{array}$ & 0.647 & -0.363 & 0.122 & 0.466 & 0.205 & 0.103 & 0.282 & $\begin{array}{l}0.8 \\
71\end{array}$ & 0.325 & 0.161 & 0.179 & 0.008 \\
\hline Project_Support & $\begin{array}{l}0.1 \\
64\end{array}$ & 0.225 & -0.15 & $\begin{array}{l}0.1 \\
38\end{array}$ & 0.17 & -0.182 & 0.091 & 0.2 & 0.158 & 0.19 & -0.038 & $\begin{array}{l}0.2 \\
87\end{array}$ & 1 & 0.18 & -0.091 & 0.102 \\
\hline $\begin{array}{l}\text { Understand_Desig } \\
\mathrm{n}\end{array}$ & $\begin{array}{c}0.1 \\
5\end{array}$ & 0.021 & -0.233 & $\begin{array}{l}0.0 \\
18\end{array}$ & 0.002 & 0.085 & 0.185 & -0.184 & -0.118 & 0.356 & 0.005 & $\begin{array}{l}0.0 \\
39\end{array}$ & 0.102 & 0.084 & -0.297 & 1 \\
\hline Value_Al & $\begin{array}{l}0.1 \\
95\end{array}$ & 0.726 & -0.05 & $\frac{0.2}{4}$ & 0.54 & -0.314 & 0.361 & 0.281 & 0.27 & -0.108 & 0.309 & $\begin{array}{l}0.4 \\
03\end{array}$ & 0.211 & -0.094 & 0.056 & 0.181 \\
\hline Value_A2 & $\begin{array}{c}0.1 \\
9\end{array}$ & 0.626 & 0.058 & $\begin{array}{l}0.2 \\
79\end{array}$ & 0.493 & -0.045 & 0.182 & 0.453 & 0.477 & 0.062 & 0.295 & $\begin{array}{l}0.3 \\
89\end{array}$ & 0 & 0.128 & 0.218 & -0.151 \\
\hline Value_A3 & $\begin{array}{l}0.3 \\
63\end{array}$ & 0.84 & 0.034 & $\begin{array}{l}0.3 \\
08\end{array}$ & 0.669 & -0.222 & 0.016 & 0.365 & 0.244 & 0.146 & 0.325 & $\begin{array}{l}0.6 \\
01\end{array}$ & 0.245 & -0.13 & 0.22 & 0.014 \\
\hline Value_B1 & $\begin{array}{l}0.3 \\
22\end{array}$ & 0.71 & 0.108 & $\begin{array}{l}0.3 \\
08\end{array}$ & 0.803 & -0.185 & 0.002 & 0.411 & 0.473 & 0.193 & 0.42 & $\begin{array}{l}0.5 \\
66\end{array}$ & 0.116 & -0.032 & 0.197 & 0.093 \\
\hline Value_B2 & $\begin{array}{l}0.4 \\
38\end{array}$ & 0.709 & 0.121 & $\begin{array}{l}0.4 \\
46\end{array}$ & 0.941 & -0.471 & 0.089 & 0.52 & 0.459 & -0.021 & 0.507 & $\begin{array}{c}0.6 \\
3\end{array}$ & 0.187 & -0.068 & 0.407 & 0.011 \\
\hline Value_B3 & $\begin{array}{l}0.3 \\
74\end{array}$ & 0.664 & -0.013 & $\begin{array}{l}0.3 \\
71\end{array}$ & 0.904 & -0.479 & 0.115 & 0.506 & 0.421 & -0.041 & 0.4 & $\begin{array}{l}0.6 \\
25\end{array}$ & 0.139 & 0.039 & 0.468 & -0.087 \\
\hline Value_E1 & $\begin{array}{l}0.0 \\
75\end{array}$ & 0.088 & -0.079 & $\begin{array}{l}0.0 \\
59\end{array}$ & 0.117 & -0.125 & 0.992 & 0.111 & -0.055 & -0.12 & -0.101 & $\begin{array}{l}0.0 \\
81\end{array}$ & 0.08 & 0.182 & 0.174 & 0.198 \\
\hline Value_E2 & $\begin{array}{l}0.0 \\
46\end{array}$ & -0.345 & 0.119 & $\begin{array}{l}0.1 \\
78\end{array}$ & -0.366 & 0.058 & 0.332 & -0.005 & -0.216 & -0.212 & -0.343 & $\begin{array}{l}0.2 \\
38\end{array}$ & -0.035 & 0.073 & 0.074 & -0.089 \\
\hline Value_E3 & $\begin{array}{l}0.1 \\
04\end{array}$ & -0.196 & -0.277 & $\begin{array}{l}0.3 \\
16\end{array}$ & -0.134 & 0.03 & 0.282 & -0.125 & -0.02 & -0.153 & -0.234 & $\begin{array}{l}0.3 \\
63\end{array}$ & -0.208 & 0 & 0.304 & 0.004 \\
\hline Value_T1 & $\begin{array}{c}0.3 \\
1\end{array}$ & 0.004 & -0.035 & 0.0 & 0.294 & 0.025 & 0.213 & 0.174 & 0.066 & -0.071 & 0.113 & $\begin{array}{l}0.0 \\
47\end{array}$ & -0.131 & -0.067 & 0.684 & -0.033 \\
\hline Value_T2 & $\begin{array}{l}0.3 \\
79\end{array}$ & 0.322 & 0.043 & $\begin{array}{l}0.0 \\
19\end{array}$ & 0.337 & 0.073 & 0.106 & 0.311 & 0.145 & -0.13 & 0.012 & $\begin{array}{l}0.2 \\
37\end{array}$ & -0.062 & 0.131 & 0.788 & -0.307 \\
\hline Value_T3 & $\begin{array}{l}0.3 \\
65\end{array}$ & 0.192 & -0.074 & $\begin{array}{l}0.0 \\
14\end{array}$ & 0.348 & 0.117 & 0.07 & 0.249 & 0.039 & -0.122 & 0.027 & $\begin{array}{l}0.0 \\
81\end{array}$ & -0.032 & -0.029 & 0.895 & -0.336 \\
\hline $\begin{array}{l}\text { Visitor_Category_ } \\
\text { Rough }\end{array}$ & $\begin{array}{l}0.0 \\
07 \\
87\end{array}$ & 0.068 & -0.273 & $\begin{array}{l}0.0 \\
07\end{array}$ & 0.038 & 0.106 & 0.133 & -0.119 & 0.071 & 1 & -0.108 & $\begin{array}{l}0.1 \\
51\end{array}$ & 0.19 & 0.466 & -0.138 & 0.356 \\
\hline Resident_Status & $\begin{array}{l}0.0 \\
72\end{array}$ & -0.065 & -0.381 & $\begin{array}{l}0.0 \\
25\end{array}$ & -0.025 & 0.098 & 0.188 & -0.058 & -0.036 & 0.466 & -0.218 & $\begin{array}{l}0.2 \\
02\end{array}$ & 0.18 & 1 & 0.022 & 0.084 \\
\hline
\end{tabular}




\section{Appendix S2 Figures}

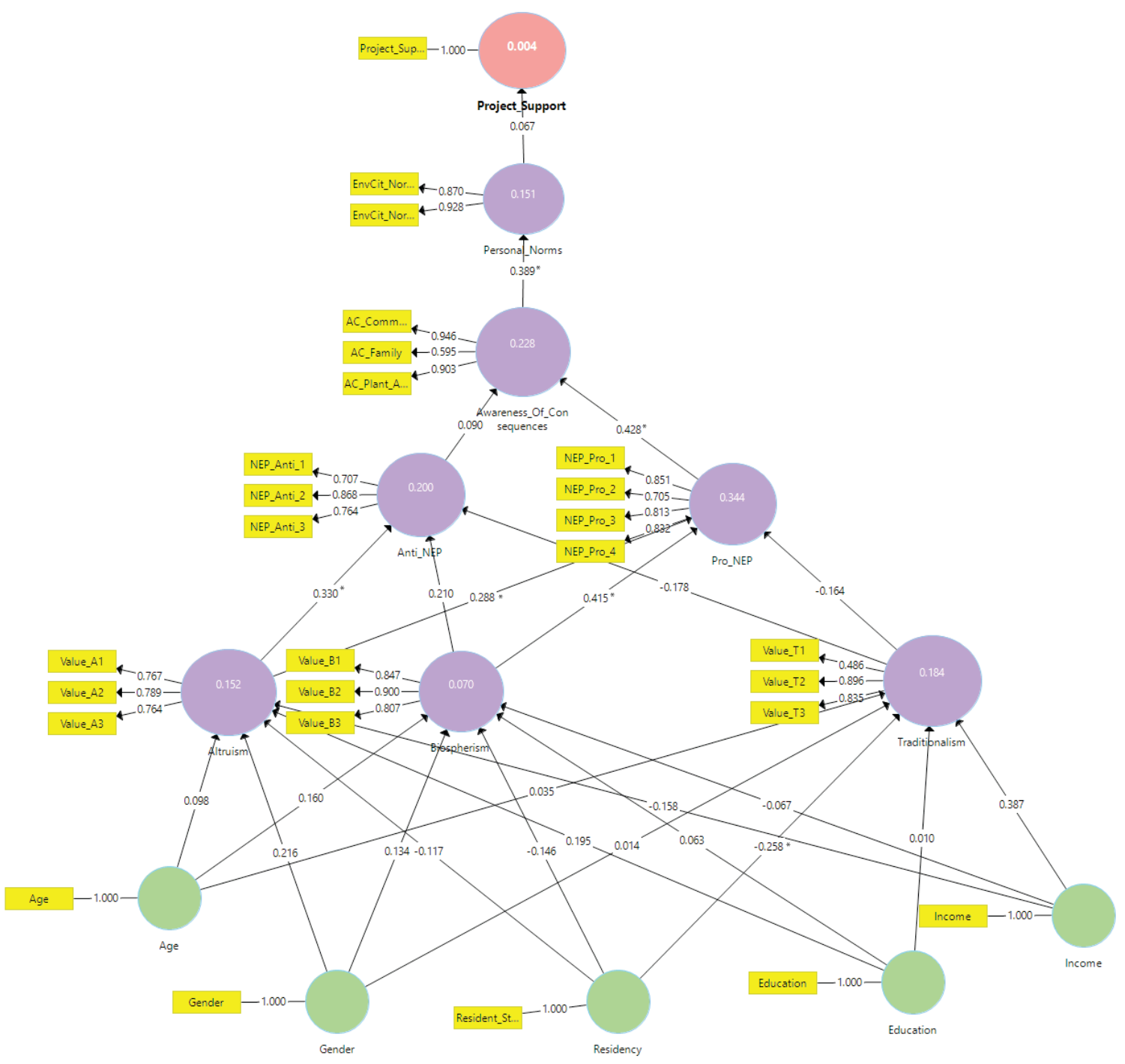

Figure S2a. Partial-least-squares (PLS) structural equation model of project support predicted by values-beliefs-norms (VBN) variables. Green circles indicate exogenous observed variables, purple circles indicate latent variables, and the pink circle indicates the main dependent observed variable 'project support'. Values within circles indicate explained variance $\left(\mathrm{R}^{2}\right)$. Values on pathways indicate regression coefficients, with "*” indicating significance at the $\mathrm{p}<0.05$ level. 


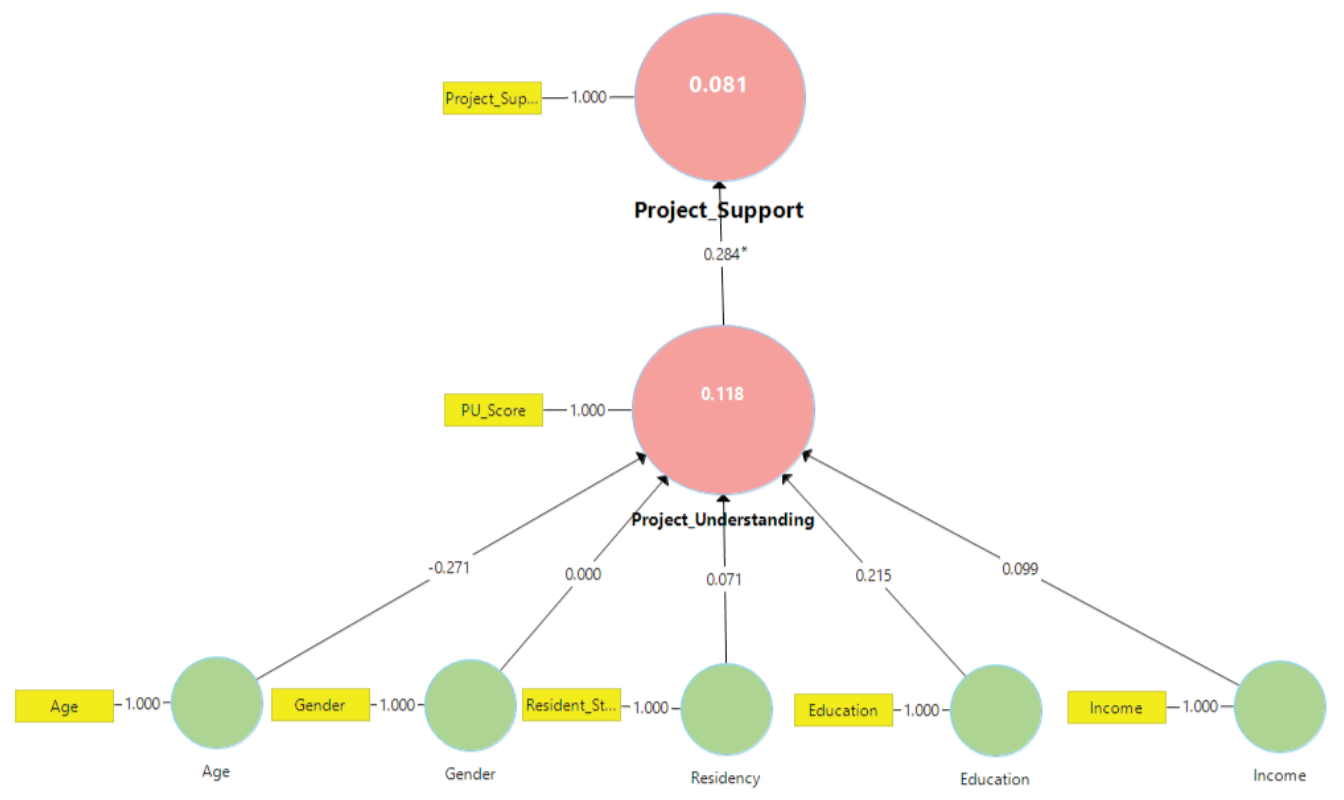

Figure S2b. Partial-least-squares (PLS) structural equation model of project support predicted by understanding of the project. Green circles indicate exogenous observed variables, and pink circles indicate endogenous observed variables. Values within circles indicate explained variance $\left(\mathrm{R}^{2}\right)$. Values on pathways indicate regression coefficients, with "*" indicating significance at the $\mathrm{p}<0.05$ level. 


\section{APPENDIX S3}

\section{DEFINITIONS OF RESTORATION SUCCESS}

One-on-one semi-structured interviews with study participants also collected qualitative data on how individuals conceptualized successful or viable pond ecosystem restoration. Qualitative data from individuals' definitions of successful coastal ecosystem restoration was coded according to social-ecological context. Under this configuration, a 'definition of success' was either mainly ecological in context, mainly social in context, or included both ecological and social elements (Table S3a). We used Pearson's chisquared tests to examine differences in the content of definitions across stakeholder groups (Rao \& Scott 1981). Intercoder reliability was calculated using Cohen's kappa (Sim \& Wright 2005) and was found to be acceptable $(\kappa=0.67)$.

Island residents cited socially-relevant criteria in their definitions of successful ecosystem restoration more frequently than tourists $($ Chi-square $=13.865, \mathrm{df}=5, \mathrm{p}<$ 0.05). Definitions that included social context commonly cited water quality issues with regards to sustaining recreational activities in the pond; as one participant stated:

"The last time I snorkeled the pond a few years ago it was downright disgusting how slimy and sludgy it had become...". Definitions characterized by ecological context often cited a desire to regrow salt marsh habitat, thereby providing support for local plant and animal species:

“...natural habitat flourishing, intact native populations not edged out by invasive species or man-made impact...".

There were fundamental differences in the way that residents and tourists conceptualized successful management. Residents tended to conceptualize success as resolving the 
environmental problems that impede human use of coastal resources (e.g. poor water quality; shellfish bed closures), while tourists tended to focus on the protection of local plant and animal species for non-extractive recreation activities (e.g. nature observation) and intrinsic values of nature. In comparison to other studies on tourism in coastal regions (Hall 2001), this pattern is counterintuitive and emphasizes the need for managers to address the relationships of different stakeholders to natural resources locally. Coastal economies often rely on tourism (Klein et al. 2004; Schubert et al. 2011), and thus require managers to balance the preferences of residents with the needs of the tourism industry. 


\section{APPENDIX S4}

\section{SUPPLEMENTARY TABLES}

Table S3a. Examples of definitions of coastal ecosystem restoration success coded as mainly ecological (1), social-ecological (2), and mainly social (3).

\begin{tabular}{lcl} 
Classification & Code & Example \\
\hline Ecological & 1 & $\begin{array}{l}\text { "If it meets its ecological goals of preservation, making sure it's continuing to sustain the } \\
\text { wildlife that use it." }\end{array}$ \\
Social-ecological & 2 & $\begin{array}{l}\text { "Sustainably returning the shoreline back to a former healthy state, enabling wildlife and } \\
\text { human life, but with an emphasis on wildlife, to thrive there." } \\
\text { Social }\end{array}$ \\
3 & "Water quality sufficient to support continued fishing and shellfishing."
\end{tabular}

Table S3b. Socioeconomic characteristics of study participants.

\begin{tabular}{|c|c|c|c|c|c|c|c|c|c|c|c|c|}
\hline & $\mathrm{N}$ & Gender & & $(y r s)$ & & & Education & & & Annual & ome & \\
\hline \multirow{3}{*}{ Residents } & \multirow[b]{2}{*}{40} & $(\mathrm{M} / \mathrm{F})$ & Median & Min. & Max & $\begin{array}{l}\text { High school - } \\
\text { Junior College }\end{array}$ & Bachelor's & $\begin{array}{c}\text { Graduate - } \\
\text { Professional } \\
\text { Degree }\end{array}$ & $\begin{array}{l}\text { Less } \\
\text { than } \\
\$ 25 \mathrm{~K} \\
\end{array}$ & $\$ 25-74 \mathrm{~K}$ & $\begin{array}{l}\$ 75- \\
149 \mathrm{~K}\end{array}$ & $\begin{array}{c}\$ 150 \mathrm{~K} \\
\text { or } \\
\text { more }\end{array}$ \\
\hline & & $18 / 18$ & 59 & 25 & 82 & 8 & 12 & 16 & 2 & 5 & 12 & 9 \\
\hline & & $50 \% / 50 \%$ & & & & $22.30 \%$ & $33.30 \%$ & $44.40 \%$ & $5.60 \%$ & $13.90 \%$ & $33.40 \%$ & $25 \%$ \\
\hline \multirow{3}{*}{ Tourists } & 49 & $21 / 23$ & 52 & 18 & 73 & 5 & 20 & 20 & 6 & 9 & 12 & 18 \\
\hline & & $47.7 \% / 52.3 \%$ & & & & $11.10 \%$ & $44.40 \%$ & $44.50 \%$ & $13.30 \%$ & $20 \%$ & $26.70 \%$ & $40 \%$ \\
\hline & & \multicolumn{2}{|c|}{$\begin{array}{l}\text { White Caucasian, Non- } \\
\text { Hispanic }\end{array}$} & \multicolumn{2}{|c|}{$\begin{array}{c}\text { African } \\
\text { American, } \\
\text { Black }\end{array}$} & Hispanic o & atino & \multicolumn{2}{|c|}{$\begin{array}{c}\text { American Indian or Alaska } \\
\text { Native }\end{array}$} & Chinese & \multicolumn{2}{|c|}{ Japanese } \\
\hline Residents & 40 & \multicolumn{2}{|c|}{34} & \multicolumn{2}{|c|}{0} & \multicolumn{2}{|c|}{0} & \multicolumn{2}{|c|}{2} & 0 & \multicolumn{2}{|c|}{0} \\
\hline Tourists & 49 & \multicolumn{2}{|c|}{37} & \multicolumn{2}{|c|}{2} & \multicolumn{2}{|c|}{3} & \multicolumn{2}{|c|}{1} & 2 & \multicolumn{2}{|c|}{1} \\
\hline
\end{tabular}

Table S3c. Difference in New Ecological Paradigm (NEP) scores and project understanding (PU) scores between individuals expressing higher and lower support for the living shoreline project, with accompanying t-statistics.

\begin{tabular}{lcccccc} 
& $\begin{array}{c}\text { Mean Among } \\
\text { Higher Support }\end{array}$ & $\begin{array}{c}\text { Mean Among } \\
\text { Lower Support }\end{array}$ & F & df & p-value & $\begin{array}{c}\text { Mean } \\
\text { Difference }\end{array}$ \\
\hline & 28.14 & 26.45 & 3.25 & 82 & 0.263 & N/A \\
NEP Score (7-35) & 3.07 & 1.92 & 0.13 & 84 & $\mathbf{0 . 0 0 2}$ & -1.151 \\
PU Score (1-4) & & & & & & \\
\hline
\end{tabular}


INTERVIEW

\section{APPENDIX S5}

\section{SUPPLEMENTARY FIGURES}

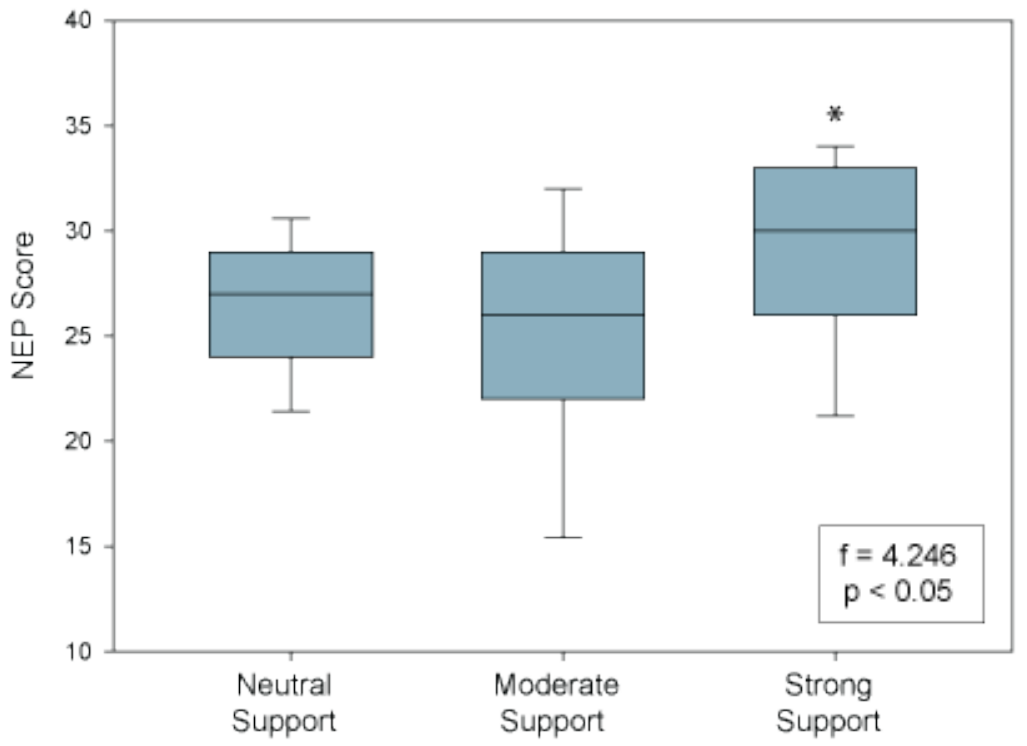

Figure S4a. The relationship between New Ecological Paradigm (NEP) scores and levels of support for the living shoreline restoration project. The mean difference in NEP score between moderate support and strong support is 3.75 points.

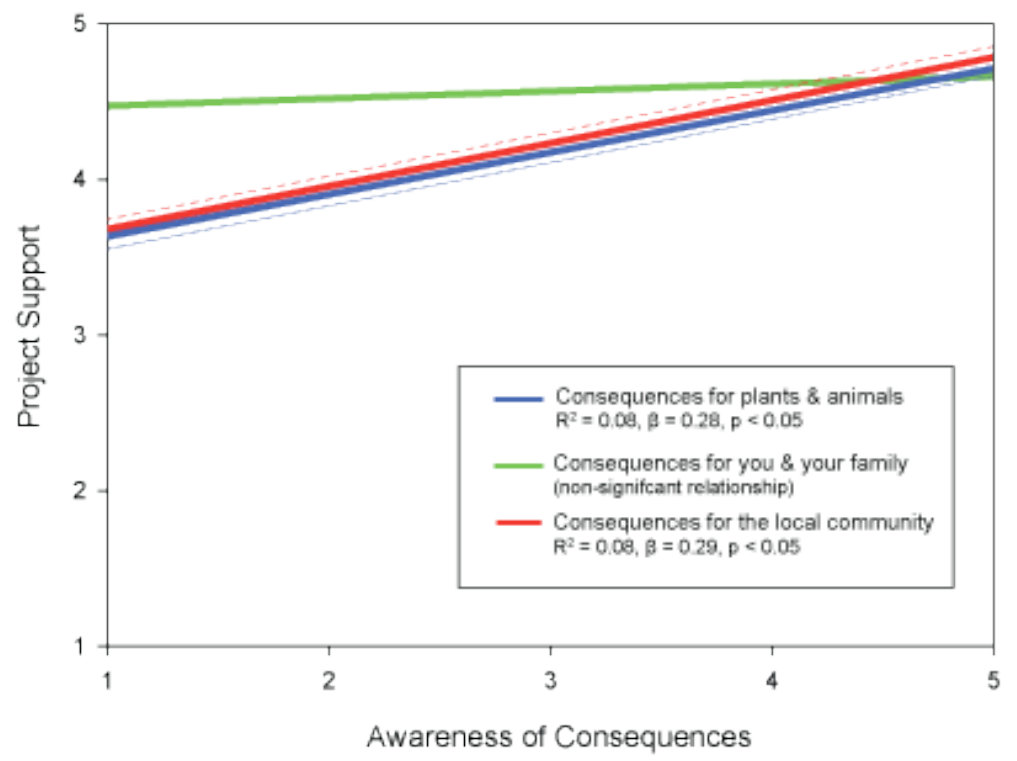

Figure S4b. The relationship between an awareness of consequences resulting from degraded coastal habitats and support for the living shoreline restoration project. 


\section{INTERVIEW}
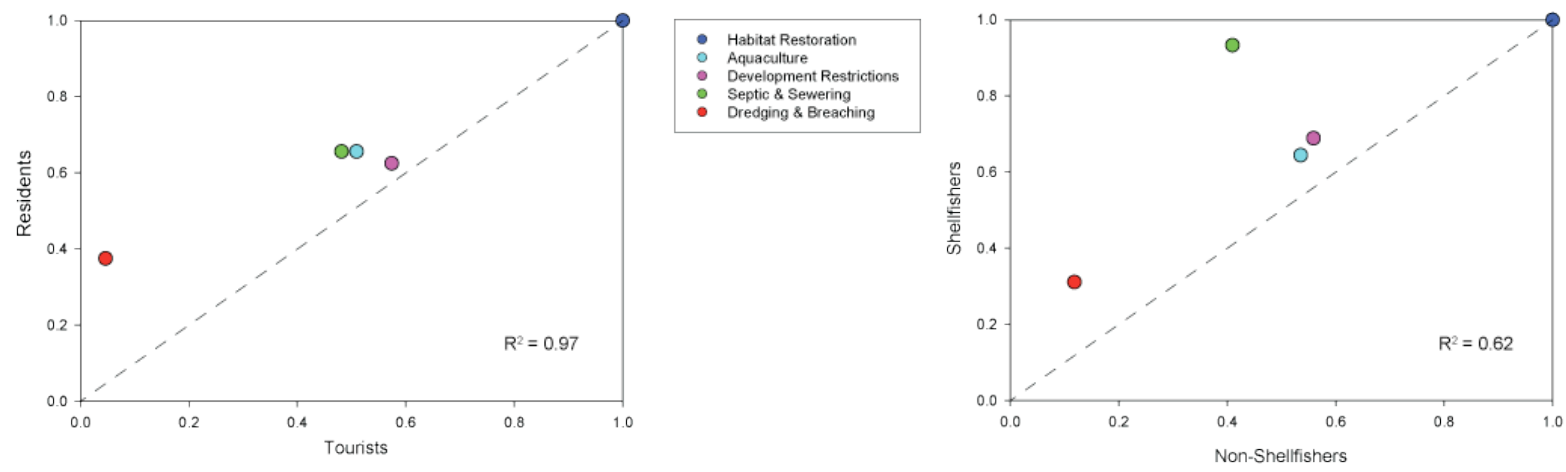

Figure S4c. Comparison of restoration strategy prioritization between a.) residents and tourists, and b.) individuals who did and did not regularly shellfish recreationally in Sengekontacket Pond. Dotted lines indicate 100\% agreement between the two groups. 


\section{INTERVIEW}

\section{APPENDIX S6}

\section{SURVEY INSTRUMENT}

My name is Lauren Josephs and I am a graduate student researcher from the University of Rhode Island. I'm conducting a social assessment of the response to a new restoration project at Felix Neck Wildlife Sanctuary. The project uses all natural, biodegradable materials to protect the nearby salt marsh from incoming waves, hopefully reducing erosion of the marsh and helping the edge of the marsh to grow back. My research is looking into the public response to this project, as well as how individuals such as yourself typically use this area. With your consent to participate, I'll ask you some simple questions about Felix Neck Wildlife Sanctuary, Sengekontacket Pond, and the restoration project.

\section{Individual Background}

1. What would you say your status on the island is?

Full-time resident $\square \quad \rightarrow 2 \quad$ Seasonal Resident $\square \quad \rightarrow 2 \& 3 a \quad$ Visitor $\square \rightarrow 3 \mathrm{~b}$

2a. Do you own, rent, or lease property on the island?

Own

Rent

Lease

None of the above; please explain:

2b. How many years have you been a full-time or seasonal resident of the island?

3a. Where are you visiting from?

3b. How many times have you visited the island?

4a. What is your current occupation?

4b. (If non-resource dependent), have you had any past occupations that you considered to be dependent on coastal natural resources?

\section{Sanctuary Activity}

5. How would you describe your activities at the wildlife sanctuary today? $\boldsymbol{O r}$ : Have you visited Mass Audubon's Felix Neck Wildlife Sanctuary since June $1^{\text {st }}, 2016$ ?

Non-visitor

Unguided Recreation

Guided Recreation $\square$

Citizen Science

\section{Site-Specific Engagement}

6. Are you currently or have you ever been a Mass Audubon member?

Current Member $\square \quad$ Past Member $\square \quad$ No $\square$

7a. Is this your first visit to Felix Neck Wildlife Sanctuary?

Yes $\square \quad$ No $\square$

7b. If no, about how many times have you visited the sanctuary? 


\section{INTERVIEW}

8a. Is this the first that you have learned of the salt marsh restoration project at Felix Neck? Yes $\square \quad$ No $\square$

$8 b$. If no, how did you first hear of it?

9. Were you involved in the project in any way?

$\square$ Voting

$\square$ Funding

Installation

Other, please indicate:

No

10. How frequently do you use Sengekontacket Pond for:

\begin{tabular}{|l|c|c|c|c|c|}
\hline & Never & $\begin{array}{c}\text { A Few Times } \\
\text { a Year }\end{array}$ & $\begin{array}{c}\text { A Few Times } \\
\text { a Month }\end{array}$ & $\begin{array}{c}\text { A Few Times } \\
\text { a Week }\end{array}$ & $\begin{array}{c}\text { Almost Daily } \\
\text { or Daily }\end{array}$ \\
\hline Recreational purposes. & $\square$ & $\square$ & $\square$ & $\square$ & $\square$ \\
\hline $\begin{array}{l}\text { Commercial or } \\
\text { professional purposes. }\end{array}$ & $\square$ & $\square$ & $\square$ & $\square$ & $\square$ \\
\hline
\end{tabular}

11. What specific activities do you typically use Sengekontacket Pond for?

\section{Definition of Success}

12. How do you envision the successful restoration of Sengekontacket Pond and its surrounding coastal lands; in other words, how would you describe 'success' in this case? 


\section{SELF-REPORT}

\section{Understanding of the Project}

13a. Would you say that you understand the goals of the restoration project?

Yes $\square \quad$ No $\square$

13b. Would you say that you understand how this particular project design will achieve those goals?

Yes $\square \quad$ No $\square$

13c. Do you think you understand the project well enough to explain it to a friend who had never heard of it?
Yes $\square$
No

\section{Project Support}

14. If we went back to when this project was being proposed, to what degree would you voice support for it?

Strongly Somewhat

Oppose $\square \quad$ Oppose $\square$

Neutral

Somewhat Strongly

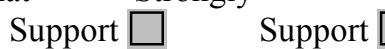

15a. If additional funding was obtained for the restoration of Martha's Vineyard's coastal ponds and their shorelines, in your opinion, where should the funding be prioritized? (Please rank your top 3 priority areas, with 1 being the highest priority)

Habitat restoration

Aquaculture and bioremediation

Septic system and sewering updates

Watershed development restrictions

Dredging and breaching of ponds

Other; please indicate:

15b. What information and/or opinion did you use to come to your decision in the previous question (Question 15a.)?

\section{General Engagement}

16. Please indicate how much you agree with the following statements: 


\begin{tabular}{|l|c|c|c|c|c|}
\hline & $\begin{array}{c}\text { Strongly } \\
\text { Disagree }\end{array}$ & Disagree & Neutral & Agree & $\begin{array}{c}\text { Strongly } \\
\text { Agree }\end{array}$ \\
\hline $\begin{array}{l}\text { I spend significant effort to stay informed on } \\
\text { issues of ecological restoration and conservation. }\end{array}$ & $\square$ & $\square$ & $\square$ & $\square$ \\
\hline $\begin{array}{l}\text { Potential ecological consequences are part of } \\
\text { what guides my behavior. }\end{array}$ & $\square$ & $\square$ & $\square$ & $\square$ \\
\hline
\end{tabular}

17. In the last year or so, have you:

\begin{tabular}{|c|l|}
\hline Yes $\square$ No $\square$ & Been an active member of an ecological restoration or conservation organization? \\
\hline Yes $\square \quad$ No $\square$ & Made a financial contribution to an ecological restoration or conservation organization? \\
\hline Yes $\square \quad$ No $\square$ & Volunteered for an ecological restoration or conservation organization? \\
\hline Yes $\square$ No $\square$ & Subscribed to a publication focused on ecological issues? \\
\hline Yes $\square$ No $\square$ & Contributed to the decision-making process on a particular ecological issue (e.g. voting)? \\
\hline Yes $\square$ No $\square$ & Voted for a political candidate at least in part because of their views on ecological issues? \\
\hline Yes $\square$ No $\square$ & Used social media to communicate your own views on an ecological issue? \\
\hline
\end{tabular}

\section{Values and Beliefs}

18. From your perspective, how much of a problem do you think the decline in health of Martha's Vineyard's coastal ponds (including Sengekontacket Pond) poses for:

\begin{tabular}{|l|c|c|c|c|c|}
\hline & $\begin{array}{c}\text { Not at all a } \\
\text { Problem }\end{array}$ & $\begin{array}{c}\text { Not much of } \\
\text { a Problem }\end{array}$ & Neutral & $\begin{array}{c}\text { Somewhat of } \\
\text { a Problem }\end{array}$ & A Serious Problem \\
\hline Plants and animals. & $\square$ & $\square$ & $\square$ & $\square$ & $\square$ \\
\hline $\begin{array}{l}\text { You and your } \\
\text { family. }\end{array}$ & $\square$ & $\square$ & $\square$ & $\square$ & $\square$ \\
\hline $\begin{array}{l}\text { The local island } \\
\text { community. }\end{array}$ & $\square$ & $\square$ & $\square$ & $\square$ & $\square$ \\
\hline
\end{tabular}

19. Which of the following groups should accept the most responsibility for fixing the declining health of Martha's Vineyard's coastal ponds (Pick one):

\begin{tabular}{|r|l|}
\hline$\square$ & Every member of the public \\
\hline$\square$ & Environmental agencies \\
\hline$\square$ & Local government \\
\hline$\square$ & Federal government \\
\hline$\square$ & Business and industry \\
\hline
\end{tabular}

20. Please indicate how much you agree with each of the following statements about the relationship of humans and the natural environment:

\begin{tabular}{|l|c|c|c|c|c|}
\hline & $\begin{array}{c}\text { Strongly } \\
\text { Disagree }\end{array}$ & Disagree & Neutral & Agree & $\begin{array}{c}\text { Strongly } \\
\text { Agree }\end{array}$ \\
\hline $\begin{array}{l}\text { If things continue on their present course, we'll soon } \\
\text { experience a major ecological catastrophe. }\end{array}$ & $\square$ & $\square$ & $\square$ & $\square$ & $\square$ \\
\hline The balance of nature is very delicate and easily upset. & $\square$ & $\square$ & $\square$ & $\square$ & $\square$ \\
\hline The earth has very limited room and resources. & $\square$ & $\square$ & $\square$ & $\square$ & $\square$ \\
\hline $\begin{array}{l}\text { Human beings are severely abusing the natural } \\
\text { environment. }\end{array}$ & $\square$ & $\square$ & $\square$ & $\square$ & $\square$ \\
\hline
\end{tabular}




\begin{tabular}{|l|l|l|l|}
\hline $\begin{array}{l}\text { The balance of nature is strong enough to cope with the } \\
\text { impacts of modern industrial nations. }\end{array}$ & $\square$ & $\square$ \\
\hline $\begin{array}{l}\text { The so-called ecological crisis facing humankind has been } \\
\text { greatly exaggerated. }\end{array}$ & $\square$ & $\square$ \\
\hline $\begin{array}{l}\text { Human ingenuity will ensure that we do not make the } \\
\text { world unlivable. }\end{array}$ & $\square$
\end{tabular}

21. Consider each of the following sets of items and indicate how important each value is as a guiding principle in your life:

\begin{tabular}{|c|c|c|c|c|c|}
\hline s & $\begin{array}{l}\text { Strongly } \\
\text { Disagree }\end{array}$ & Disagree & Neutral & Agree & $\begin{array}{c}\text { Strongly } \\
\text { Agree }\end{array}$ \\
\hline $\begin{array}{l}\text { Social justice, correcting injustice, care for the } \\
\text { weak }\end{array}$ & $\square$ & $\square$ & $\square$ & $\square$ & $\square$ \\
\hline $\begin{array}{l}\text { Influential, having impact on people and } \\
\text { events }\end{array}$ & $\square$ & $\square$ & $\square$ & $\square$ & $\square$ \\
\hline Wealth, material possessions & $\square$ & $\square$ & $\square$ & $\square$ & $\square$ \\
\hline Equality, equal opportunity for all & $\square$ & $\square$ & $\square$ & $\square$ & $\square$ \\
\hline Authority, the right to lead or command & $\square$ & $\square$ & $\square$ & $\square$ & $\square$ \\
\hline Unity with nature, fitting into nature & $\square$ & $\square$ & $\square$ & $\square$ & $\square$ \\
\hline A world of peace, free of war and conflict & $\square$ & $\square$ & $\square$ & $\square$ & $\square$ \\
\hline Self discipline, resistance to temptations & $\square$ & $\square$ & $\square$ & $\square$ & $\square$ \\
\hline $\begin{array}{l}\text { Respecting the earth, harmony with other } \\
\text { species }\end{array}$ & $\square$ & $\square$ & $\square$ & $\square$ & $\square$ \\
\hline Family security, safety for loved ones & $\square$ & $\square$ & $\square$ & $\square$ & $\square$ \\
\hline Protecting the environment, preserving nature & $\square$ & $\square$ & $\square$ & $\square$ & $\square$ \\
\hline Honoring parents and elders, showing respect & $\square$ & $\square$ & $\square$ & $\square$ & $\square$ \\
\hline
\end{tabular}

\section{Individual Background}

22. What is your age?

\section{What is your gender?}

24 . What is your ethnicity? (check all that apply)

$\begin{array}{ll}\square \text { White Caucasian - Non-Hispanic } & \square \text { Mexican } \\ \square \text { Hispanic or Latino } & \square \text { Chinese } \\ \square \text { African American, Black } & \square \text { Japanese } \\ \square \text { American Indian or Alaskan } & \square \text { Korean } \\ \text { Native } & \square \text { Indian }\end{array}$


25a. Do you consider yourself to be a religious person?

$\square$ Yes $\quad \square$ No

25b. If yes, which religion are you affiliated with?

26. What is the highest level of education that you have completed?

$\square$ Less than high school

High school diploma or GED

$\square$ Bachelor's degree

$\square$ Associate's, vocational, or junior college degree

$\square$ Graduate or professional degree

27. What was your household income last year?

$\square$ Less than $\$ 25,000$
$\square \$ 25,000-49,000$
$\square \$ 50,000-74,999$
$\square \$ 75,000-99,999$
$\square \$ 100,000-149,000$
$\square \$ 150,000-199,999$
$\square \$ 200,000$ or more

